\title{
DISERTACIONES
}

Grupos minoritarios y estigmatizados: diversidad funcional, religiosa, étnica, afectivo-sexual o de identidad de

\section{REPRESENTACIÓN DE MINORÍAS E INSTAGRAM: ANÁLISIS DEL ESPACIO DIGITAL DE PROTESTA DEL PROCÉS}

Minorities and Instagram Representation: An Analysis of the Digital Space for Procés Protests

Representação de minorias e Instagram: análise do espaço digital de protesto do Procés

Javier Acevedo Nieto, Universidad de Salamanca (España)

acevedo@usal.es

Recibido: 14 de septiembre del 2021

Aprobado: 30 de septiembre del 2021

Fecha de prepublicación: 18 de enero del 2022

\section{RESUMEN}

En los últimos años las redes sociales como Instagram se han erigido en espacios que prolongan la acción de protestas y manifestaciones trasladándolas a la interfaz de la red social. La protesta se ha movilizado de espacios reales y concretos a lo que autores como Zappavigna han denominado espacios digitales de protesta. El objetivo del trabajo es estudiar cómo se construyen estos espacios digitales de protesta. Se realiza un análisis de contenido cualitativo de las imágenes posteadas por usuarios de redes sociales con una muestra de nueve imágenes de usuarios de Instagram filtradas a partir de hashtags clave que reflejan distintos momentos de las protestas contra la sentencia del Procés. Se aplican diversas técnicas como el análisis formal e iconográfico, y la teoría del framing como marco para el análisis del discurso y la categorización de imágenes. Los resultados informan sobre cómo se relacionan los usuarios y cómo interactúan con la protesta a través de formas de activismo audiovisual. Se 


\section{DISERTACIONES}

Grupos minoritarios y estigmatizados: diversidad funcional, religiosa, étnica, afectivo-sexual o de identidad de género en la comunicación

ISSN: 1856-9536

Doi: https://doi.org/10.12804/revistas.urosario.edu.co/disertaciones/a.11077

Volumen 15, Número 1 / Enero-junio 2022

Versión PDF para imprimir desde

http://revistas.urosario.edu.co/index.php/disertaciones

concluye que el imaginario colectivo se cimienta en una serie de iconos simbólicos que se definirán para terminar de desvelar el entramado de recursos visuales que ayudan a comprender la forma de relacionarse y construir una memoria digital de la protesta. Este trabajo proporciona un método básico de análisis y una reflexión sobre la integración de las narrativas minoritarias en la cobertura periodística.

Palabras clave: Instagram; minoría; espacio digital protesta; postdigital.

\section{ABSTRACT}

In recent years, social networks such as Instagram have become spaces that prolong the action of protests and demonstrations and transfer it to the social network interface. Protests have moved from real and concrete spaces to what authors like Zappavigna have called digital protest spaces. The objective of this work is to study how these digital protest spaces are constructed based on a qualitative content analysis of the images posted by social network users. A sample of nine images of Instagram users was filtered with key hashtags that reflect different moments of the protests against the Procés. Various techniques were applied, such as formal and iconographic analysis, and framing theory as a framework for discourse analysis and image categorization. The results inform about how users relate to each other and how they interact with protests using forms of audiovisual activism. It is concluded that the collective imagination is founded upon a series of symbolic icons that will be defined to finish unveiling the network of visual resources that help to understand how to relate and build a digital memory of the protest. This work provides a basic method of analysis and reflection on the integration of minority narratives in journalistic coverage.

Keywords: Instagram; minority; digital protest space; post-digital.

\section{RESUMO}

Nos últimos anos, redes sociais como o Instagram tornaram-se espaços que prolongam a ação de protestos e manifestações e a transferem para a interface da rede social. O protesto passou de espaços reais e concretos para o que autores como Zappavigna chamaram de espaços digitais de protesto. 0 objetivo do trabalho é estudar como esses espaços digitais de protesto são construídos. Se realiza uma análise de conteúdo qualitativa das imagens postadas por usuários de redes sociais com uma mostra de nove imagens de usuários de Instagram filtradas a partir de hashtags chave que refletem distintos momentos dos protestos contra a sentença do Procés. Se aplicam diversas técnicas como a análise formal e iconográfica, e a teoria do framing como marco para a análise do discurso e a categorização de imagens. Os resultados informam sobre como se relacionam os usuários e como interagem com o protesto por meio de formas de ativismo audiovisual. Se conclui que o imaginário coletivo é baseado em uma série de ícones simbólicos que serão definidos para finalizar o desvelamento da rede de recursos visuais que ajudam a compreender como se relacionar e construir uma memória digital do protesto. Este trabalho proporciona um método básico de análise e reflexão sobre a integração dessas narrativas minoritárias em possíveis coberturas jornalísticas.

Palavras-chave: Instagram; minoria; espaço digital de protesto; pós-digital. 


\section{DISERTACIONES}

\section{Introducción}

Esta investigación pretende centrarse en un análisis de las imágenes subidas, compartidas y comentadas en la plataforma de Instagram durante las protestas acaecidas en los días posteriores a la sentencia del Procés. Para tal fin, se procederá a analizar cualitativamente imágenes provenientes de usuarios y fotoperiodistas de la red social para establecer una reflexión acerca de la performatividad de la llamada imagen postdigital, es decir, su papel como portadora de sentido y su capacidad de resignificar un evento político y social, tomando en consideración conceptos como interfaz, espacio público digital de protesta e intersubjetividad. Se trata de un estudio de caso cuya selección muestral no responde a criterios de representatividad, sino más bien, una primera aproximación a algunos de los conceptos que se van a señalar. Un estudio que parte de la idea de espacio público digital puesto que Instagram y, en general, toda la red, actúa como archivo descentralizado de una hiperhistoria que, en palabras de Watkins (2014, p. 3) "genera imaginarios descentralizados que no remiten a actos de protesta en sí, sino a una representación de estos". Son espacios digitales basados en intercambios de interacciones y publicaciones que reescriben el discurso mediático sobre la realidad inserto en otros medios de comunicación. Se habla de intersubjetividad porque los actuales códigos digitales han creado nuevos espacios de convivencia y sociabilización online. Entender cómo interpretarlos e integrarlos en la cobertura mediática es uno de los grandes retos de los estudios sobre la comunicación. López-Cleries (2020, p. 5) señala que la aparición de una nueva estética sensorial basada en los tingles - cosquilleos- define la experiencia sensorial, táctil y visual de toda persona que emplea un dispositivo para acceder a Internet. Estos códigos digitales, por lo tanto, van a recrear una experiencia de navegación e interacción inmediata, mediada por distintas capas de lenguaje - desde la invisibilidad del código web hasta la hipervisibilidad de enlaces e imágenes- que conforman una experiencia, en ocasiones superficial e insensible, que necesita ser resignificada. Es ahí donde el papel del periodista, del comunicador y también del usuario habitual se torna vital, pues es necesario huir de una concepción de lo digital como medio nocivo (López-Cleries, 2020, p. 6). En ese sentido, existen diversas aproximaciones sobre la problemática de lo digital en la construcción identitaria y psicológica del individuo; la hedonía depresiva descrita por Mark Fisher (2009) o la idea de lo público y la individualización del estrés inserta en el concepto de capitalismo emocional propuesto por Illouz (2007, p. 30).

Esta investigación trabaja con publicaciones de Instagram entendidas como micronarrativas individuales, ya que tal y como apunta Ferreira Martín (2020, p. 18), el modelo narrativo de Internet corta historias en lugar de narrarlas. La actual dependencia tecnológica, la incorporación de diversas interfaces de software y dispositivos de hardware, y la permanente atomización del individuo a un estructuralismo de pequeños mensajes e interacciones. El fin último de toda micronarrativa es producir una experiencia estética del proceso de comunicación, como apunta Groys (2016, p. 15). Se ha pasado de una relación interactiva y horizontal con las TIc a una relación de dependencia y sometimiento a las mismas (Floridi, 2016, p. 51). La esencia de la tecnología actual no es tanto tecnológica como englobadora (Hui, 2019, p. 3) y su giro hacia una tendencia eminentemente audiovisual motiva a que este tipo de estudios puedan servir como aproximaciones genuinas para estudiar procesos de legitimación y representación online de minorías. Por lo tanto, es un estudio que puede englobarse dentro del constante proceso de alfabetización mediática que incluye el control de lenguajes y soportes que promueven la comunicación en todas sus dimensiones (Izquierdo Magaldi et al., 2013, p. 79). 


\section{DISERTACIONES}

ESTUDIOS

El análisis se centra en cómo por medio de esta red social se ha generado una intersubjetividad en la que distintas minorías - jóvenes, sectores LGTBI+ y minorías políticas - fagocita el foco de la reivindicación política durante los acontecimientos, manifestaciones y protestas acaecidas en Barcelona tras la sentencia del juicio del Procés. Zappavigna (2016, p. 271) destaca la temporalidad recreada en el timeline de Instagram: el diseño de la red social favorece la aparición de imágenes que no se caracterizan por su instantaneidad. Zappavigna (2016, p. 273) relaciona la condición de representación del acontecimiento al constructo identitario que se edifica en el momento en el que el usuario concibe el acontecimiento como un evento de desarrollo de su estilo e imagen personal. La persistencia, la replicabilidad, la escalaridad y la accesibilidad a las imágenes de este acontecimiento son factores que median en la repercusión informativa del evento; factores, por otra parte, alejados de criterios informativos tradicionales.

A partir de estas ideas generales que se definirán con mayor concisión en la propuesta de objetivos, el análisis cualitativo del corpus de imágenes seleccionadas pretende desvelar algunas de las tácticas de estas minorías en su representación visual de las protestas de Barcelona y reflexionar sobre la construcción de un imaginario colectivo sobre la protesta partiendo de la interfaz y la capacidad unificadora de experiencia de Instagram. Para tal fin, el concepto central del análisis será el de espacio digital de protesta, propuesto por Treré et al. (2017, p. 2), revisado por San Cornelio y Gómez Cruz (2019). El análisis se articulará a partir de una revisión cualitativa de los distintos enfoques insertos en las nueve publicaciones de Instagram seleccionadas, así como una revisión de las relaciones intersubjetivas que se establecen.

Se profundiza también en la idea de imaginario digital, el cual se concreta en espacios digitales de protesta que trasladan las reivindicaciones que acontecen en las calles a la interfaz y el timeline de la red social. De este modo, como afirman Treré y Barassi (2015, p. 4) no hay que concebir el imaginario digital como otro simulacro o concepto nómada, sino como un espacio en la red en el que verdaderamente confluyen significados compartidos, prácticas políticas, ideologías y reacciones que expanden el significado del activismo digital. La definición final de estos imaginarios es la de formas polimórficas -imágenes, vídeos, memes, entre otros- en las que minorías sociales proponen sistemas de valores que se imbrican en la estructura tecnológica y expanden la infraestructura material de la red social hacia un complejo ideológico (Treré et al., p. 407).

Por último, Catalá Domenech (2010) ha entendido la interfaz como el espacio de confluencia entre las instancias cognitivas del individuo y la dimensión concreta y dramatúrgica del objeto de la imagen. En esa interfaz se desarrolla una iconicidad que es la base para desentrañar todas las relaciones sugeridas en esta cultura-red, a través de la cual San Cornelio y Gómez Cruz (2019) proponen ahondar en las imágenes y redes sociales que reflejan las protestas en Cataluña mediante la idea de valencia de la imagen (San Cornelio \& Gómez Cruz, 2019).

\section{Metodología}

\section{Sistema de análisis}

La metodología empleada se basó en un análisis cualitativo de una pequeña muestra de nueve imágenes de usuarios de Instagram filtradas a partir de hashtags clave que reflejan distintos momentos de las protestas contra la sentencia del Procés entre el 14 de octubre y 1 de noviembre del 2019. 


\section{DISERTACIONES}

La selección de fotografías condensa las protestas acaecidas en Barcelona tras la sentencia del Procés. Dichas protestas surgen contra la sentencia del Tribunal Supremo que condenaba a penas de prisión de entre 9 y 13 años a nueve líderes políticos catalanes, entre ellos, el exvicepresidente de la Generalitat Oriol Junqueras. Descartado el delito de rebelión, el Tribunal español basó su sentencia en los delitos de sedición, malversación y apreció indicios de episodios de violencia en el otoño del 2017 durante la proclamación de la República Catalana. Rápidamente las protestas se extendieron por toda Cataluña y en menor medida por otros puntos del Estado español. Estas manifestaciones pueden enmarcarse en el movimiento político y reivindicativo surgido alrededor de las denominadas Marchas por la Libertad, una serie de marchas que partieron desde Vic, Tárrega, Tarragona, Girona, Berga y Casteldefels congregándose en Barcelona el 18 de octubre del 2019. Un total de 525.000 asistentes -según datos de la Guardia Urbana - marcharon por las calles de Barcelona arropados por organizaciones como Tsunami Democrático, Asamblea Nacional Catalana, Òmnium Cultural y los Comités de Defensa de la República, coincidiendo con una convocatoria de huelga general el mismo día. Las protestas consistieron en sentadas pacíficas, cortes de calles, enfrentamientos puntuales con fuerzas del orden y manifestantes independentistas, protestas en universidades y episodios de contraprotestas organizados por manifestantes nacionalistas españolas. El total de heridos se cifra en 593, empezando en las protestas del 14 de octubre con la ocupación del Aeropuerto de Barcelona, El Prat, siguiendo el 15 con las barricadas frente a la Delegación del Gobierno y recrudeciéndose el 16 con enfrentamientos y desórdenes públicos en diferentes emplazamientos en el centro de Barcelona y el barrio del Eixample, que implicaron la creación de barricadas con contenedores a los que se les prendió fuego. En ese sentido, las imágenes seleccionadas para este trabajo se centran en esta temática: fotografías de incendios y sujetos que se posicionan de distinto modo ante ellos.

\section{Contexto social y periodístico}

La situación política y su traslado al espacio urbano en forma de protesta y activismo fue uno de los hechos noticiosos más relevantes del 2019. La cobertura de los medios se centró en los enfrentamientos y copó titulares durante prácticamente tres semanas. El relato mediático de los hechos ahondó primero en la repercusión y contenido de la sentencia personalizando el efecto de la sentencia en Oriol Junqueras en el caso de El Mundo (Martialay \& Marraco, 2019), desgranando las claves de la sentencia como hizo el periódico ABC (Arrechedera \& Villanueva, 2019), explicitando la reacción de políticos españoles como hizo El País (Marcos, 2019) o admitiendo análisis contrapuestos como el efectuado por ElDiario.es (Escolar, 2019) que destaca su falta de sentido jurídico. El relato mediático de las protestas nuevamente osciló entre encuadres noticiosos medianamente negativos, condenatorios y centrados en la violencia. En líneas generales, las grandes líneas editoriales de España se centraron en las repercusiones violentas y enfrentamientos entre algunos manifestantes y las fuerzas de seguridad y orden público: es el caso de El País hablando de la radicalización de la protesta con el apoyo de Quim Torra (Noguer \& Baquero, 2019), Antena 3 recogiendo el atestado policial y destacando el número de agentes heridos en los distintos altercados, la descripción de una oleada de violencia en Cataluña realizada por La Vanguardia (Tort, 2019), la asignación de culpabilidad en el supuesto ente independentista y su asociación con la totalidad de las protestas recogida por Agencia EFE (2019), o los periodistas heridos que según el encuadre habían sido heridos a manos de los denominados CDR o la detención de la fotoperiodista Anna Punsí por parte de la policía. Los encuadres mediáticos de algunos medios catalanes 


\section{DISERTACIONES}

ESTUDIOS

Grupos minoritarios y estigmatizados: diversidad funcional, religiosa, étnica, afectivo-sexual o de identidad de

género en la comunicación

ISSN: $1856-9536$

Doi: https://doi.org/10.12804/revistas.urosario.edu.co/disertaciones/a.11077

Volumen 15, Número 1 / Enero-junio 2022

Versión PDF para imprimir desde

http://revistas.urosario.edu.co/index.php/disertaciones

como Betevé se centraron en los enfrentamientos, en las tensiones del orden público y concentraciones universitarias desligándose de actos violentos o señalamiento de culpables, similar encuadre está en 324 sobre las cargas policiales o las protestas. Por lo tanto, los distintos medios enmarcaron las protestas con encuadres generalmente negativos que ahondaban en la violencia y sus repercusiones en forma de heridos y detenidos, construyendo un relato con bandos diferenciados y asignación de culpabilidad. De los distintos medios rastreados para construir una breve panorámica del hecho noticioso narrado en medios, solo Betevé entrevistó a algunos manifestantes para que explicaran su postura.

El análisis propuesto en este trabajo se centra en la construcción del espacio digital de protesta, el cual está condicionado por el punto de vista de las minorías que acudieron a ella. Con lo cual, el punto de vista difiere del relato noticioso en tanto y cuando no aspira a ser materia mediática sino reacción colectiva. Por su parte, los medios apenas recogieron las muestras de reacciones en redes a la protesta. Esta cobertura se limita a describir la información de los tweets citados, sin profundizar en cómo las redes asimilan el hecho mediático de la protesta al margen del discurso de los medios. Lo mismo sucede con la viralización de la instantánea subida a Instagram por la usuaria fitness_mama, etiquetada con atributos como "polémica", "disturbios" o en el caso de otra usuaria como sandra.kisterna "estupefacción" ante su vídeo realizando twerking frente a las protestas. Puede concluirse que el posicionamiento de los medios ante la construcción del espacio digital de protesta, la intersubjetividad y la construcción de una memoria colectiva no ahonda más allá de la condena ni analiza el posicionamiento del usuario, la puesta en escena o las reacciones del resto de usuarios.

Se asiste entonces a un proceso de framing en el que las manifestaciones audiovisuales de protesta digital son encuadradas de manera negativa y sin apenas peso en los atributos que definen la saliencia de un hecho mediático como las protestas de Barcelona. Para entender la relevancia del framing hay que acudir a Tankard (2001), quien destaca que este tiene múltiples ramificaciones, y es un proceso lógico en el cual el periodista decide centrarse en un sujeto o realidad desde un punto de vista decidido de antemano. Tras eso se define lo que él denomina una agenda de atributos, una selección de términos que definan ciertas características que se quieran realzar de esa realidad informativa. Estos términos se convierten en palabras clave que inundan el discurso mediático y son absorbidas por el receptor, reforzando la saliencia de esos términos escogidos en temas que integran la agenda pública. Es una narrativa guiada, que encuadra una realidad y dicta en qué términos debe contarse. La agenda de atributos referida a las manifestaciones audiovisuales de la protesta se limita a atributos señalados e insertos en el lenguaje periodístico como "polémica", "estupefacción", "postureo" o "jauría”. Son términos negativos que condicionan el debate sobre la pertinencia, la estetización de la protesta, la interacción social y la negociación intersubjetiva en interfaces como Instagram.

Semetko y Valkenburg (2000) van más allá y proponen cinco frames o tipos de encuadre. El primer encuadre es el de conflicto -entre individuos, grupos o naciones-; el segundo es el de interés humano -historias extraordinarias, apelar a la emoción-; el tercero es el de atribución de la responsabilidad - piezas informativas que apuntan a un culpable o señalan a un sector de la población-; el cuarto es el de consecuencias económicas -incidir en problemas económicos y señalar de nuevo causas y culpables interesadamente- , y el último es el moral -cuestiona dilemas éticos sobre temas abiertos al debate como el aborto o la inmigración-. Las noticias encuadradas se valen de estos marcos, disponen de palabras clave y el receptor comienza a reflejar los juicios de valor mediático incorporando esas palabras a su discurso y lexicón, guiando su juicio crítico sobre la realidad. En el caso de la 


\section{DISERTACIONES}

ESTUDIOS

cobertura de las imágenes de Instagram, los encuadres oscilan entre la atribución de responsabilidad, señalando la actitud de supuesta indiferencia de los instagramers y usuarios que postean material alrededor de la protesta; y el moral, abriendo con frecuencia debates o sentencias sobre la pertinencia de este material, juzgando la actitud o cuestionando el papel de la juventud en las protestas. Tan analizado como ha sido el proceso de framing hasta el día de hoy, sigue siendo un mecanismo útil para catalogar la cobertura mediática y trazar un breve estado de la cuestión alrededor de cómo determinado periodismo ha interiorizado la cobertura de este nuevo fenómeno de activismo digital.

Por su parte, Kim et al. (2002) demuestran que dichos objetos sociales e informativos, sí que influyen en la percepción de la audiencia con base en el lenguaje empleado. La selección de atributos traducidos en palabras clave tiene un impacto medido en un receptor que pese a no ser pasivo se ve amenazado por la infoxicación moderna. Por otra parte, la teoría del framing se vale de lo que Miller denominaría dispositivos de encuadre (Igartua \& Humanes, 2004). Estos dispositivos son imágenes, metáforas, símbolos y palabras que facilitan la identificación de encuadres en la noticia, y que facilitan la elaboración de un mapa de encuadres que permite detectar estructuras similares en otras noticias, incluso de distintos medios. Actúan de manera similar a los atributos, pero condicionan la recepción de la noticia, por ejemplo, a partir de la selección de la imagen de portada y el pie de página que le acompaña. Como apuntan Dubois y Villenueve-Siconnelly (2019, p. 229) el framing es particularmente útil en escenarios como las protestas del Procés porque enfatizan el modo en el que se presentan los hechos una vez el paradigma de la agenda setting queda superado debido a que el análisis no se centra tanto en la relevancia informativa sino en el alcance mediático. Se apunta, por lo tanto, a encuadres específicos de un asunto concreto, siguiendo las tesis de Entman que apunta que un encuadre que es culturalmente congruente y se opone a un cierto consenso social siempre tendrá mayor saliencia y adhesión a un aparato adecuado de imágenes, relatos y términos (Dubois \& Villenueve-Siconnelly, 2019, p. 230). Para desvelar esa congruencia cultural y también el consenso mediático que se ve vulnerado se ha seguido la investigación de Semetko y Vanderburg a partir de un análisis de contenido que desvele los encuadres preexistentes (Dubois \& Villenueve-Siconnelly, 2019, p. 232).

Hay que destacar que el encabezado de noticias sobre imágenes surgidas en el espacio digital de protesta remite a encuadres negativos que no se cuestionan el discurso social inserto en las imágenes (véase figura 1). Autores como Kuntsman (2017, p. 14) han destacado la importancia del selfie acuñando el concepto de ciudadanía selfie (selfie citizenship) como una herramienta de movilización de la conciencia política. Las prácticas tecnosociales (Blas, 2013, p. 2) insertas en las imágenes no son vistas por los medios como una oportunidad para aproximarse a nuevas formas de mostrar la intimidad, vulnerar el espacio, reinterpretar la idea de ciudadanía o incluso reapropiarse del imaginario político. 
DESCUBRE

\title{
Polémica por la influencer que 'posturea' con la violencia en Cataluña
}

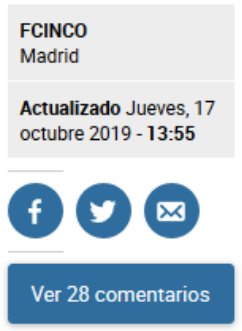

\begin{abstract}
Una única foto acompañada de la frase "Barcelona is on fire" ha sido suficiente para que las redes ardan, pero contra la influencer que usa la violencia en Cataluña para conseguir más likes
\end{abstract}

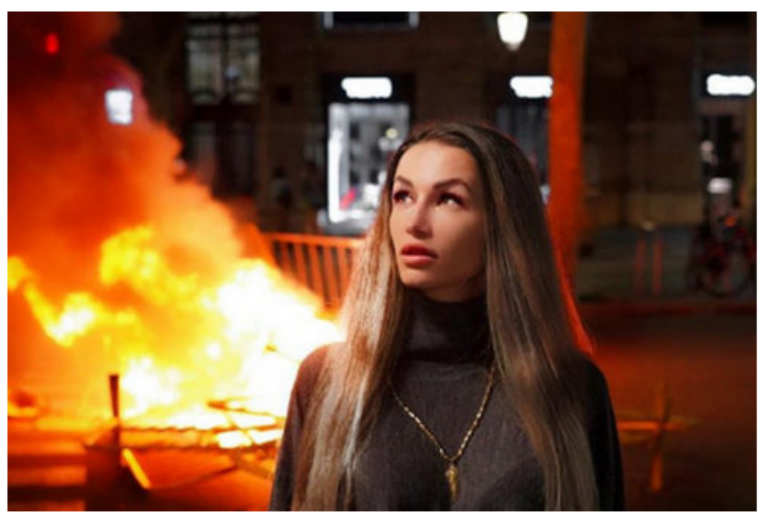

Fitness Mama en los disturbios de Barcelona. INSTAGRAM

Figura 1. Portada 1, Diario El Mundo

\section{MÁs las llamas en Barcelona}

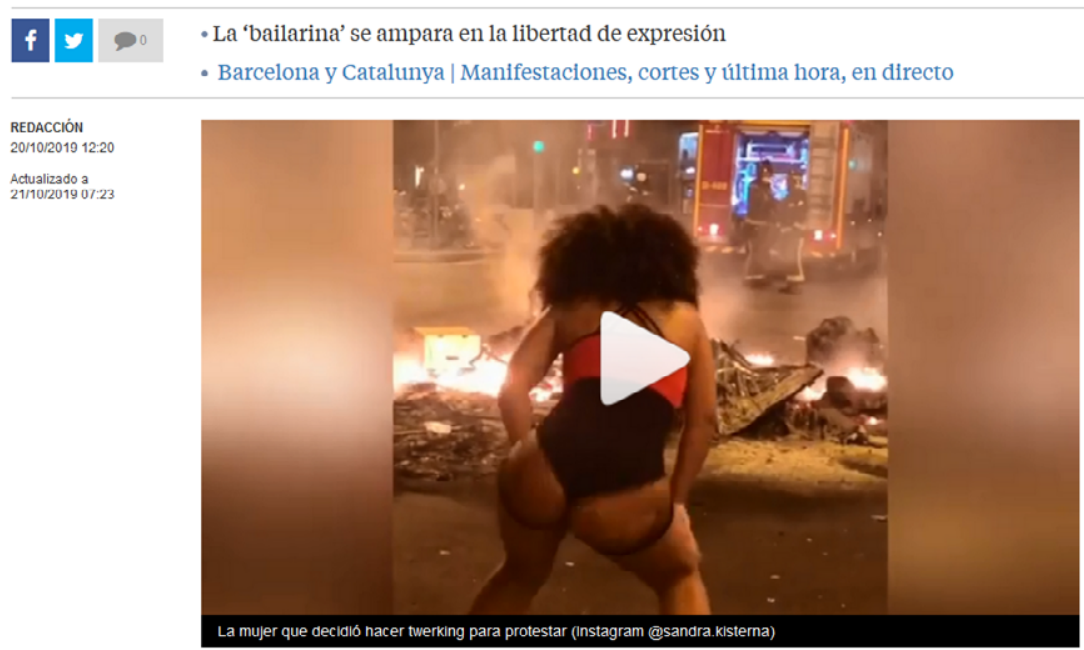

Figura 2. Portada 2, La Vanguardia 


\section{Una influencer rusa «posturea» en Instagram con los disturbios de Barcelona de fondo}

- A Elena Rybalchenko le están lloviendo las críticas por la imagen que ha subido a la red social

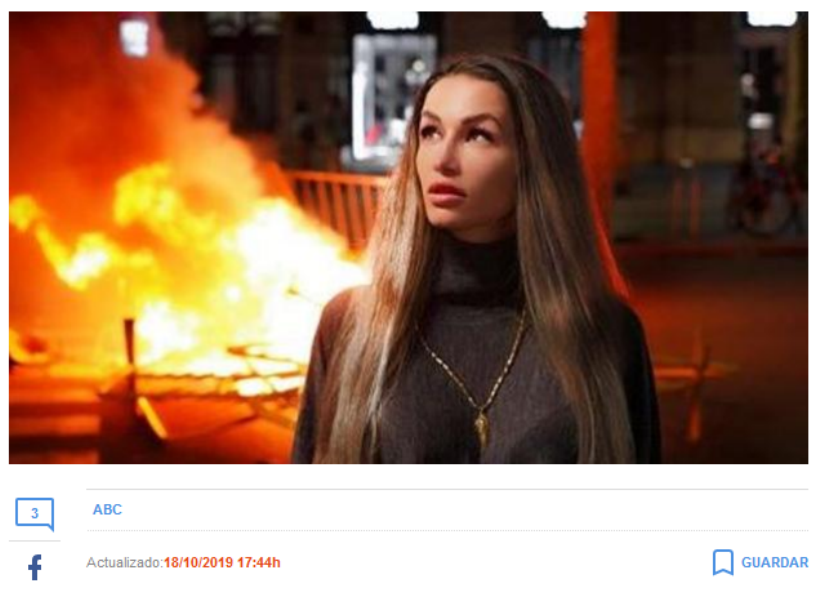

Figura 3. Portada 3, ABC

Asimismo, dentro de este proceso de ingeniería inversa, estas imágenes actúan como testigos de un acontecimiento, lo cual resulta crucial para la actividad periodística. No se limitan a ser testigos pasivos, sino que de manera activa producen un conocimiento de la realidad por medio de una posición privilegiada, conformando una aproximación legitimada por la aparición del rostro o el cuerpo (Koliska \& Roberts, 2015, p. 1674). Las imágenes se convierten, por lo tanto, en un archivo de momentos con un valor determinado frente a la tradicional idea de la imagen como singularidad invalorable (Van Dijck, 2008). El selfie como narrativa personal impulsa una serie de cambios en el periodismo, asociando el acto de atestiguar la presencia en un acontecimiento con una prueba de verdad (Koliska \& Roberts, 2015, p. 1676). Por lo tanto, la aproximación a estas imágenes requiere por parte del periodismo una actitud distinta relacionada con el valor del punto de vista inserto en ellas, en el relato que proponen, en su capacidad para distanciarse de la narración periodística. Estos testimonios audiovisuales conforman un sentido de identidad colectiva potenciado por una visión de la tecnología y las redes sociales con base en sus capacidades democráticas (Anderson, 2019, p. 193). Por otra parte, Anderson (2019, p. 202) ha señalado a través de un análisis comparativo y una investigación centrada en organizaciones como Òmnium Cultural, la relevancia de las redes sociales para transmitir cuestiones relacionadas con un sentir colectivo alrededor de una causa política orquestado por minorías cuya voz no se hace sentir en las portadas de los medios tradicionales. 


\section{DISERTACIONES}

ESTUDIOS

\section{"Barcelona en llamas": el postureo 'instagramer' que causa cabreo}

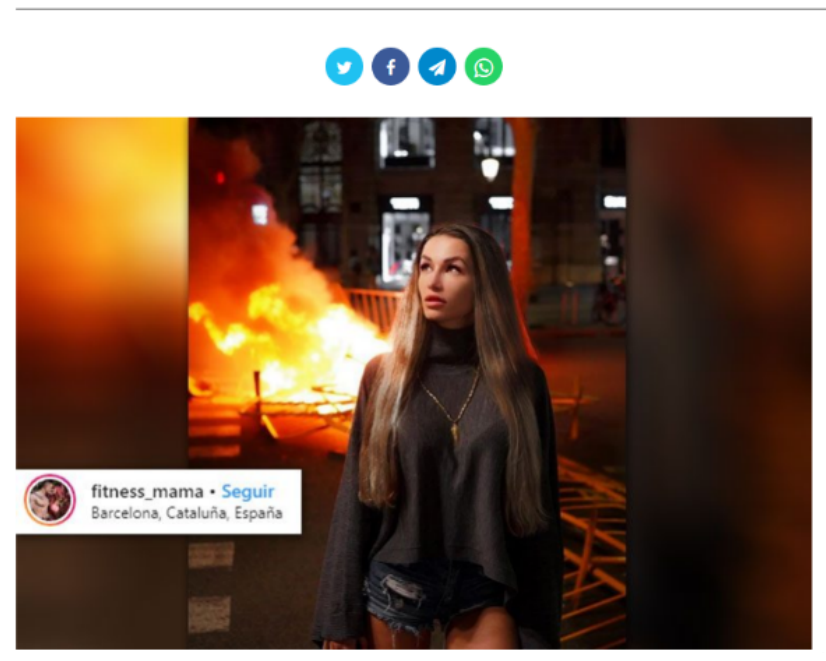

Figura 4. Portada 4, Público

\section{Resultados}

Como hemos avanzado, la metodología empleada se basó en un análisis cualitativo de una muestra de ocho imágenes de usuarios de Instagram y dos vídeos filtrados a partir de hashtags clave que reflejan distintos momentos de las protestas contra la sentencia del Procés entre los días 14 de octubre y 1 de noviembre del 2019.

Se utilizaron diversas técnicas como el análisis formal e iconográfico, que incluye una fase descriptiva y una segunda fase analítica que relaciona la imagen con el contexto. También se tuvo en cuenta la teoría el framing (Goffman, 1974) como marco para el análisis del discurso y la categorización de los tipos de imágenes analizadas. Este enfoque, si bien es abundante en el análisis textual y discursivo de las protestas, no lo ha sido en el caso de las imágenes (Doerr \& Teune, 2008). Finalmente, más allá de la imagen como artefacto cultural, se analizan las interacciones de los usuarios con dichas imágenes y el papel de la plataforma digital Instagram como espacio para la protesta. Otro elemento para tener en cuenta fue el concepto de intersubjetividad y el análisis cualitativo y de contenido empleado para desvelar los mecanismos que conforman una cierta congruencia cultural alrededor de la memoria prostética y colectiva que organiza el espacio digital de protesta. Para enmarcar el análisis formal de las imágenes, previamente se procede a resumir las características básicas de documento audiovisual en una pequeña tabla. En primer lugar, se dan a conocer las imágenes que se van a analizar: 


\section{DISERTACIONES}

ESTUDIOS

Grupos minoritarios y estigmatizados: diversidad funcional, religiosa, étnica, afectivo-sexual o de identidad de género en la comunicación

ISSN: $1856-9536$

Doi: https://doi.org/10.12804/revistas.urosario.edu.co/disertaciones/a.11077

Volumen 15, Número 1 / Enero-junio 2022

Versión PDF para imprimir desde

Hashtag: \#barcelonariots

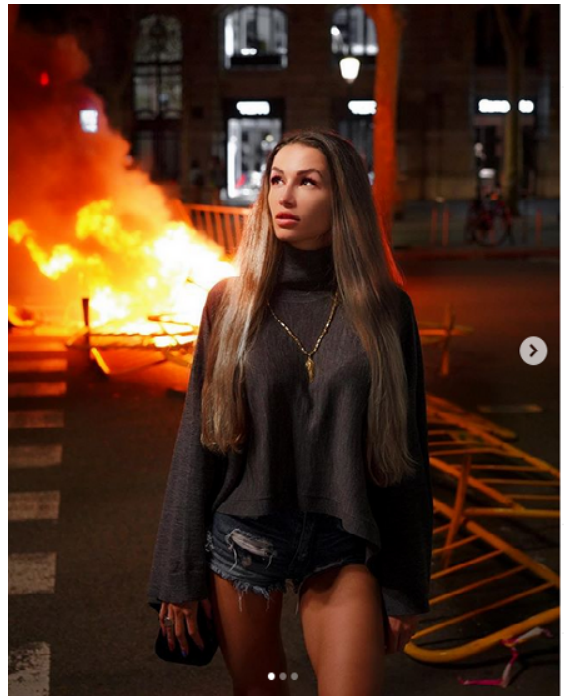

(3) fitness_mama $\cdot$ Seguir (3) fitness_mama BARCLLONA IS ON FIRL

Впереди, сзади тебя, слева и справа -

везде огонь

Вокруг взрывы, над головой

вертолеты ге , шум лопастей и

Јта ночь - словно голливудски й

боевик

сегодня в сториз.

Листайте фото

\#barcclona \#barcclonatoday

\#catalunya \#barcelonariots

\#sentenciaproces

\#libertatpresospolitics

\#independenciacatalunya

$\bigcirc \bigcirc \uparrow$

17.780 Me gusta

DE OCTUBRE

Figura 5. Imagen 1: Instagram de fitness_mama

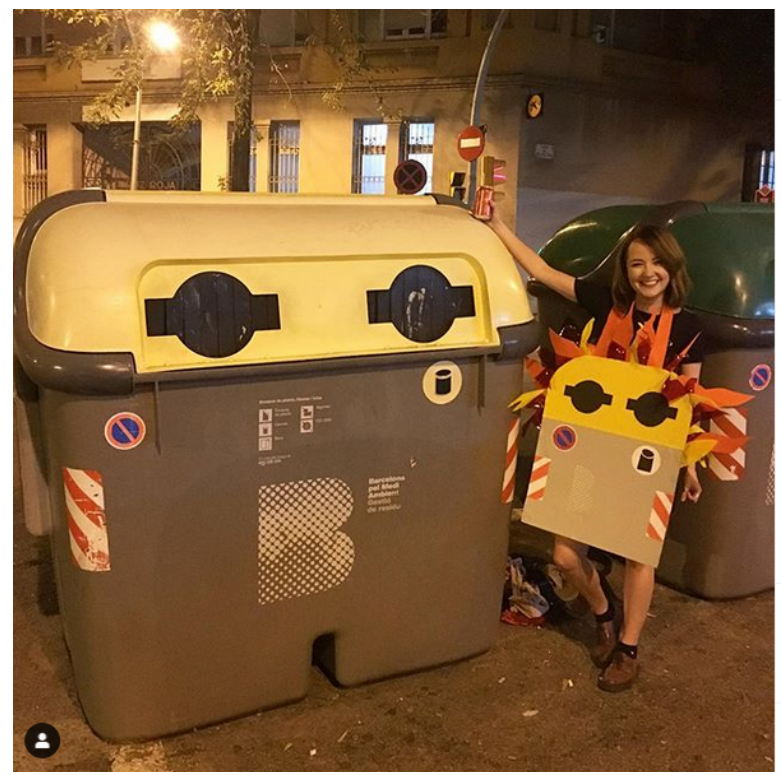
2. tinyhandsbigheart - Seguir
(14) barcelonink $(-$
6 días 1 Me gusta Responder
9. marialyttle1 (ㅇ) :-:) you've halloween costumes for years!! 6 días 1 Me gusta Responder
9. caoimhetracey This is so good hahahahaha
6 días 1 Me gusta Responder
- superloumac You top the Halloween costumes every year (4).
6 días 1 Me gusta Responder

\section{$\bigcirc \bigcirc \uparrow$}
98 Me gusta
HACE 6 DAAS

Figura 6. Imagen 2: Instagram de tinyhandsbigheart 


\section{DISERTACIONES}

ESTUDIOS

Grupos minoritarios y estigmatizados: diversidad funcional, religiosa, étnica, afectivo-sexual o de identidad de género en la comunicación

ISSN: 1856-9536

Doi: https://doi.org/10.12804/revistas.urosario.edu.co/disertaciones/a.11077

Volumen 15, Número 1 / Enero-junio 2022

Versión PDF para imprimir desde

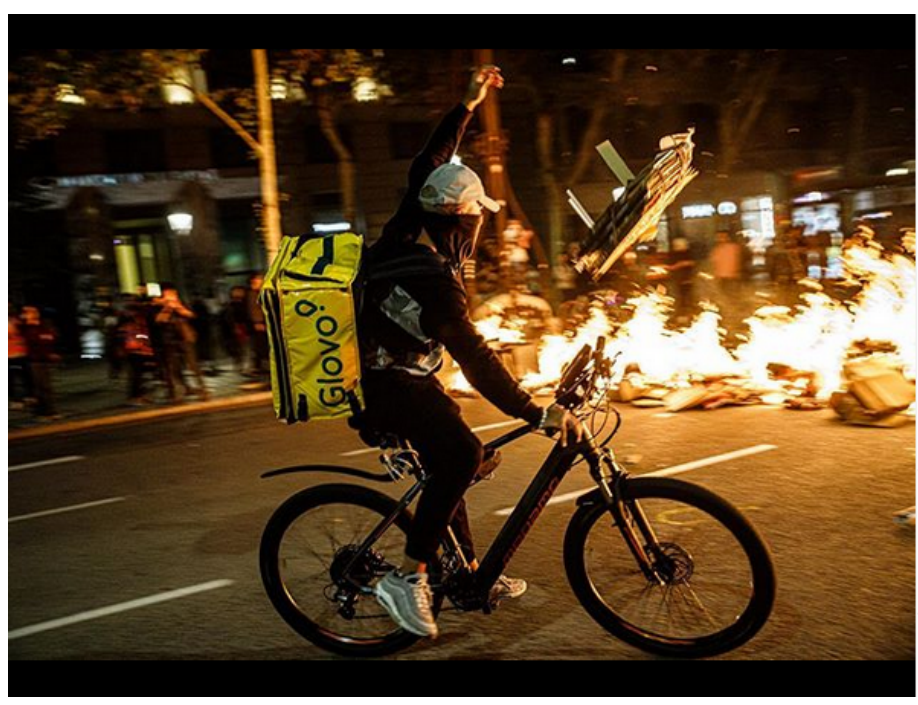

jordiborrasfoto $\diamond \cdot$ Seguir

jordiborrasfoto Dimarts 15

d'octubre, avalots a Barcelona com a resposta a la sentència contra polítics $i$ dirigents socials independentistes. Un repartidor de Glovo llança combustible a una barricada al Passeig de Gràcia. \#revoltacatalana \#photojournalism

\#fotoperiodisme \#catalunya \#catalonia

1 sem

An laieta_laieta Quines fotos més

$\bigcirc \bigcirc \varphi^{\uparrow}$

8.622 Me gusta

24 DE OCTUBRE

Figura 7. Imagen 3: Instagram de jordiborrasfoto

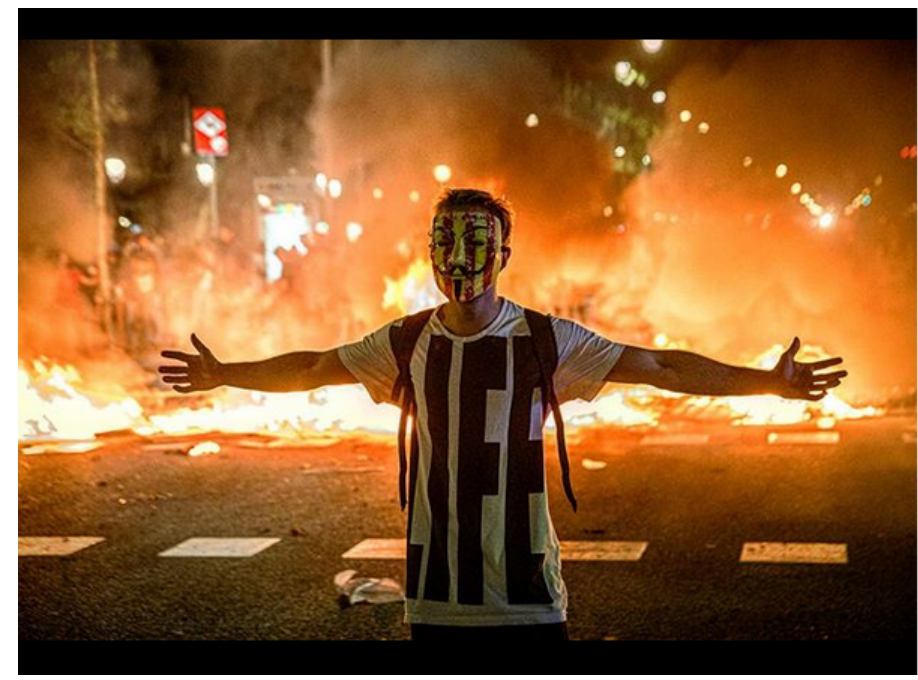

jordiborrasfoto $* \cdot$ Seguir

jordiborrasfoto $\$$ Nova nit d'avalots a Barcelona. \#tsunamidemocràtic \#catalunya \#catalonia \#photojournalism 2 sem

(-) acasaperlateulada Savi Strubell 2 sem 47 Me gusta Responder - Ver respuestas (3)

\section{$\bigcirc Q \uparrow$}

20.474 Me gusta

16 DE OCTUBRE

Figura 8. Imagen 4: Instagram de jordiborrasfoto 


\section{DISERTACIONES}

ESTUDIOS

Grupos minoritarios y estigmatizados: diversidad funcional, religiosa, étnica, afectivo-sexual o de identidad de género en la comunicación

ISSN: $1856-9536$

Doi: https://doi.org/10.12804/revistas.urosario.edu.co/disertaciones/a.11077

Volumen 15, Número 1 / Enero-junio 2022

Versión PDF para imprimir desde

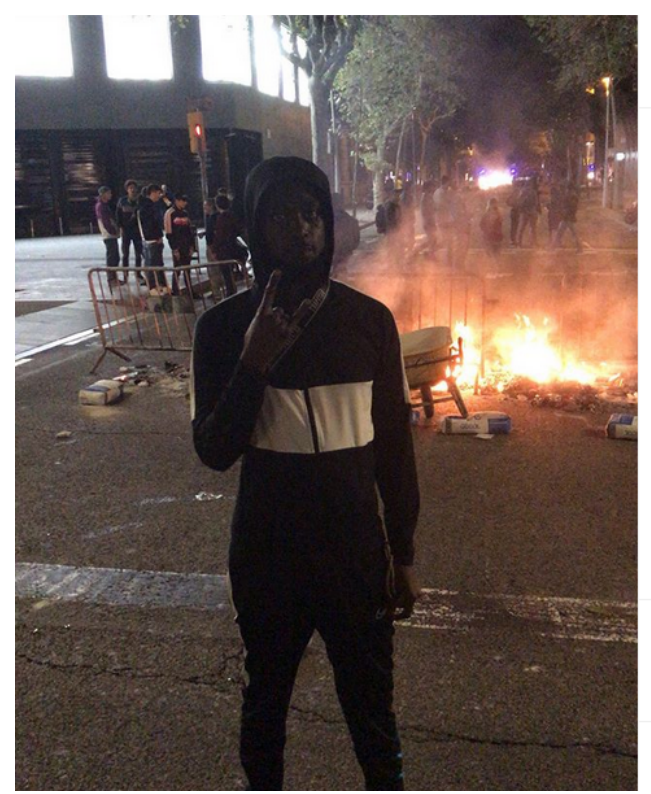

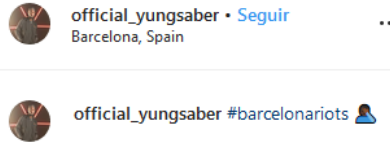

2 sem

(

nemztagram Hard photo
2 sem 1 Me gusta Respond

(17) onefootman 000

2 sem 1 Me gusta Responder

(2) crystalizer22 (2) (2) don't take

part now

2 sem 1 Me gusta Responder

$0 \bigcirc \stackrel{\uparrow}{\uparrow}$

W

175 Me gusta

17 DE OCTUBRE

Figura 9. Imagen 5: Instagram de oficial_yungsaber

Hashtag \#sentenciaproces

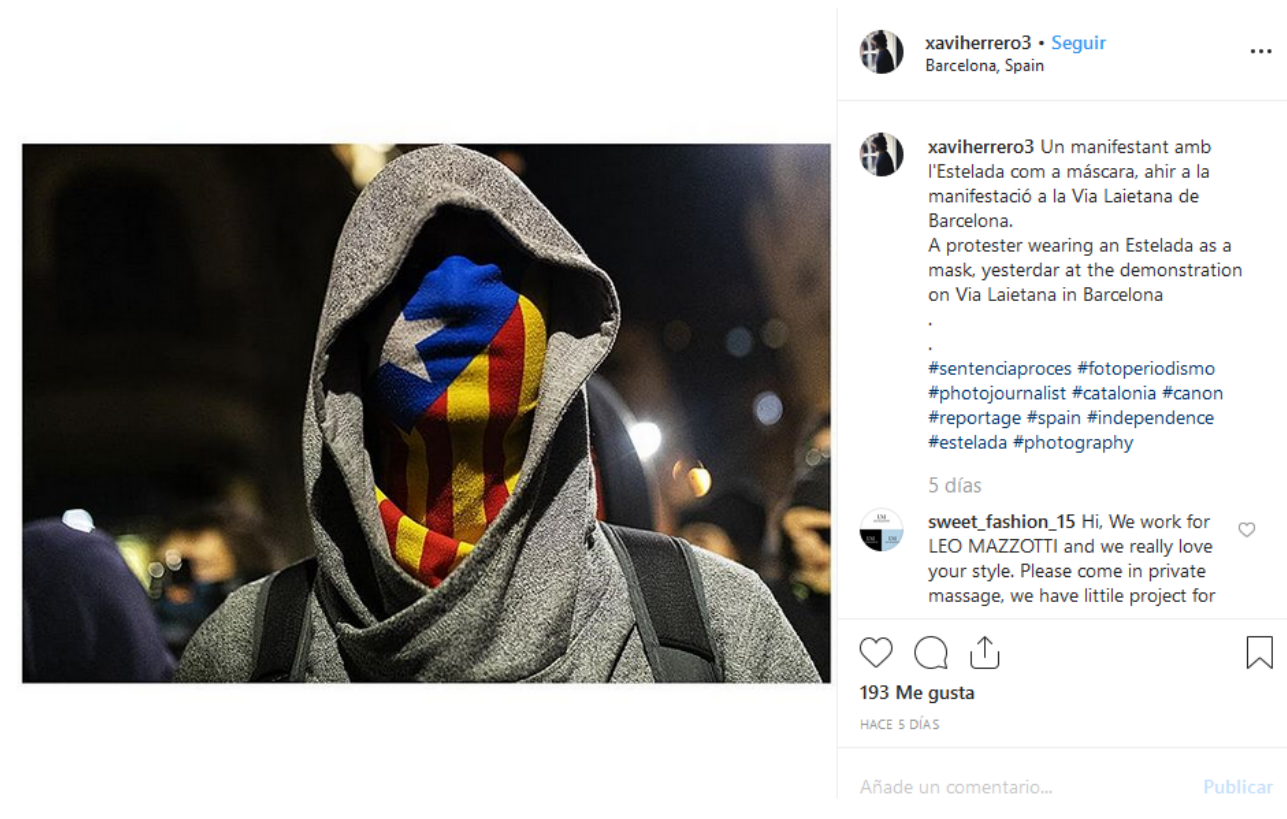

Figura 10. Imagen 6: Instagram de xaviherrero3 


\section{DISERTACIONES}

ESTUDIOS

Grupos minoritarios y estigmatizados: diversidad funcional, religiosa, étnica, afectivo-sexual o de identidad de género en la comunicación

ISSN: $1856-9536$

Doi: https://doi.org/10.12804/revistas.urosario.edu.co/disertaciones/a.11077

Volumen 15, Número 1 / Enero-junio 2022

Versión PDF para imprimir desde
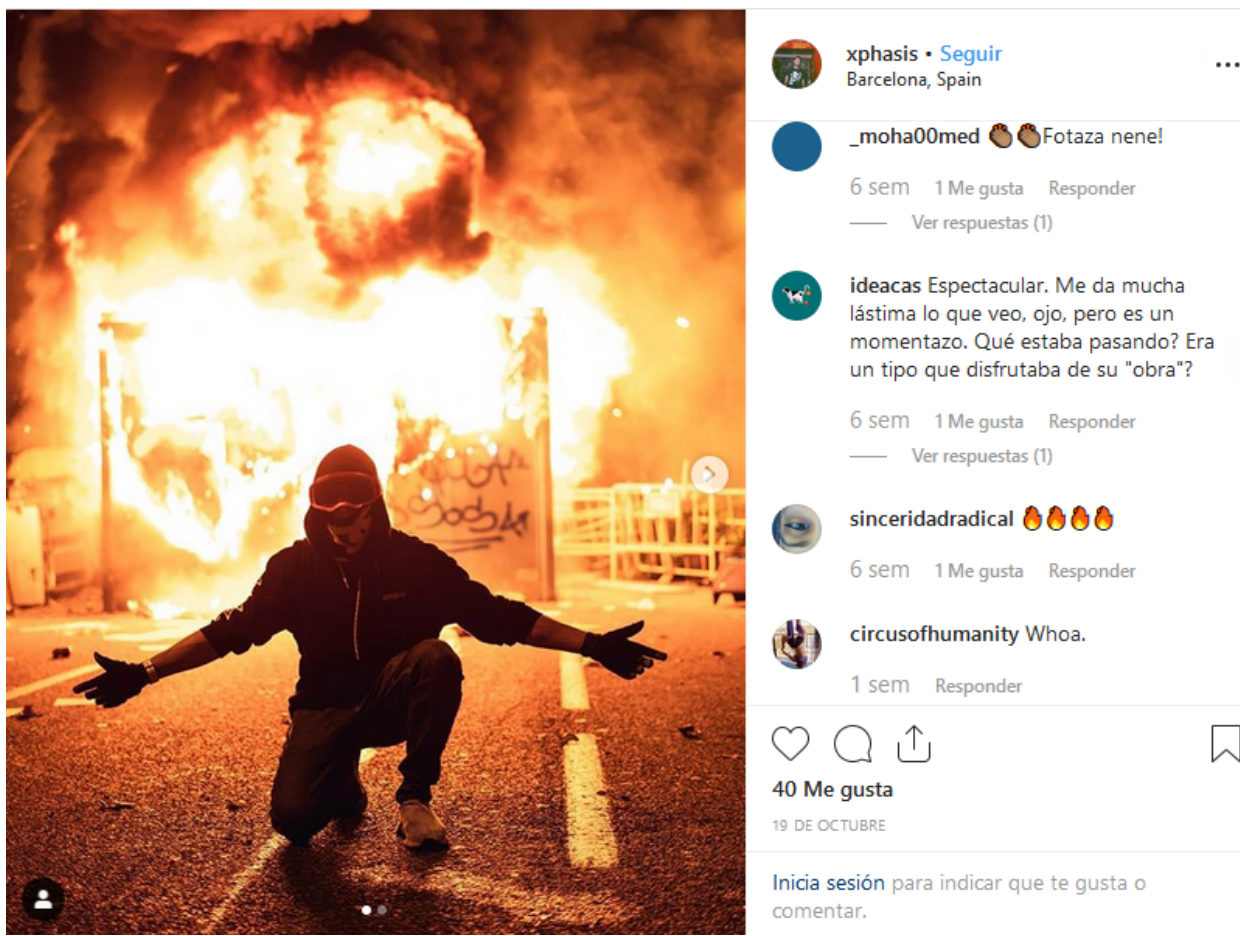

Figura 11. Imagen 7: Instagram de xphasis

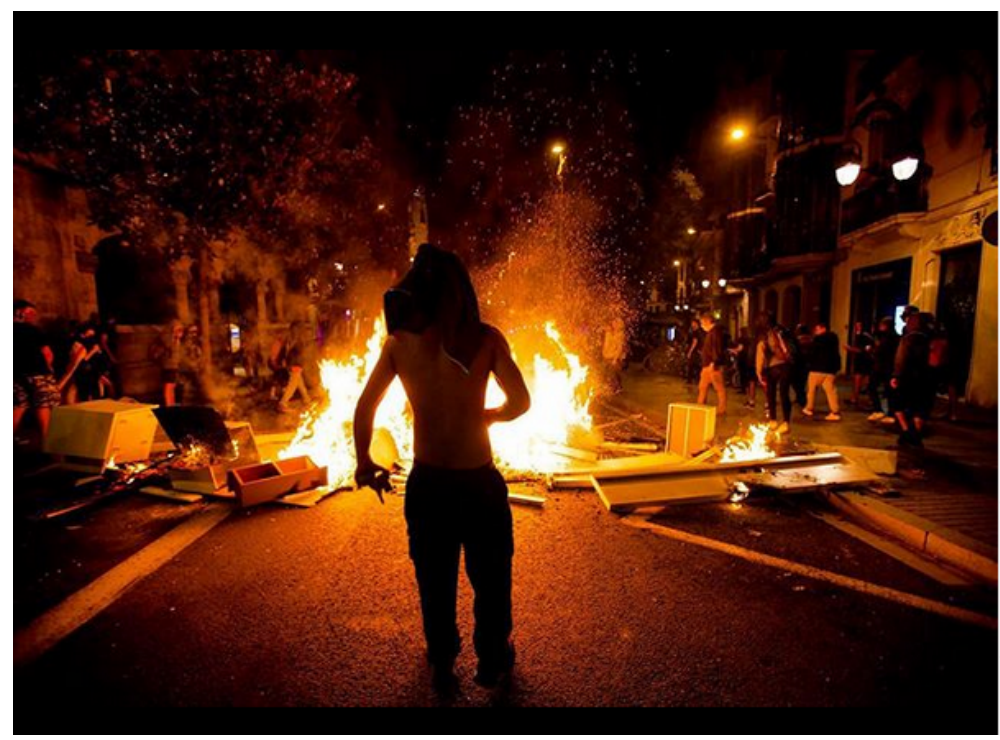

99 victoria_rovira $\cdot$ Seguir

99 victoria_rovira Per segona nit consecutiva, Barcelona condemna la sentència del judici del procés. (CVictòria Rovira; Barcelona; 2019. For the second consecutive night, Barcelona condemns the trial judgment.

\#tsunamidemocràtic \#judgment \#barcelona \#photojournalist

\#photojournalism

\#freepoliticalprisoners

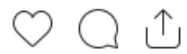

120 Me gusta

16 DE OCTUBRE

Inicia sesión para indicar que te gusta o comentar.

Figura 12. Imagen 8: Instagram de victoria_rovira 


\section{DISERTACIONES}

ESTUDIOS

Grupos minoritarios y estigmatizados: diversidad funcional, religiosa, étnica, afectivo-sexual o de identidad de género en la comunicación

ISSN: 1856-9536

Doi: https://doi.org/10.12804/revistas.urosario.edu.co/disertaciones/a.11077

Volumen 15, Número 1 / Enero-junio 2022

Versión PDF para imprimir desde

http://revistas.urosario.edu.co/index.php/disertaciones

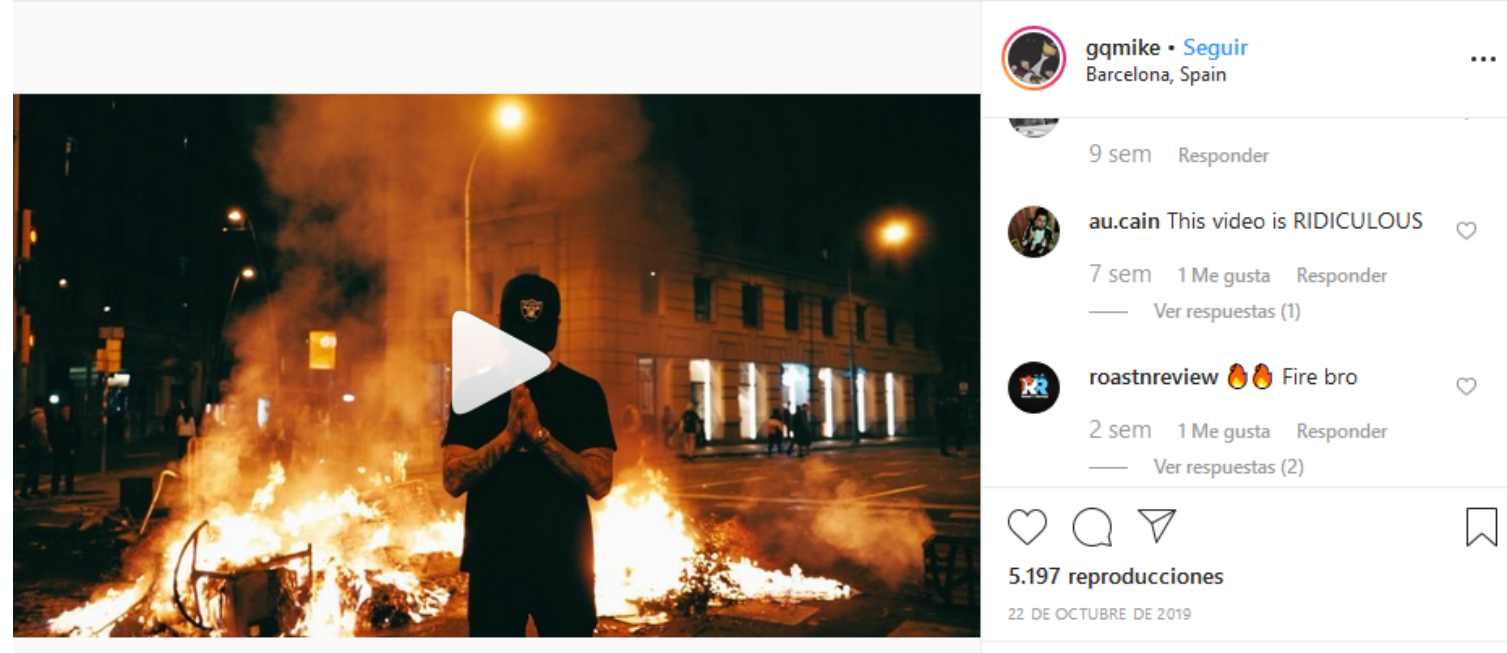

Figura 13. Vídeo 1: Instagram de gqmike

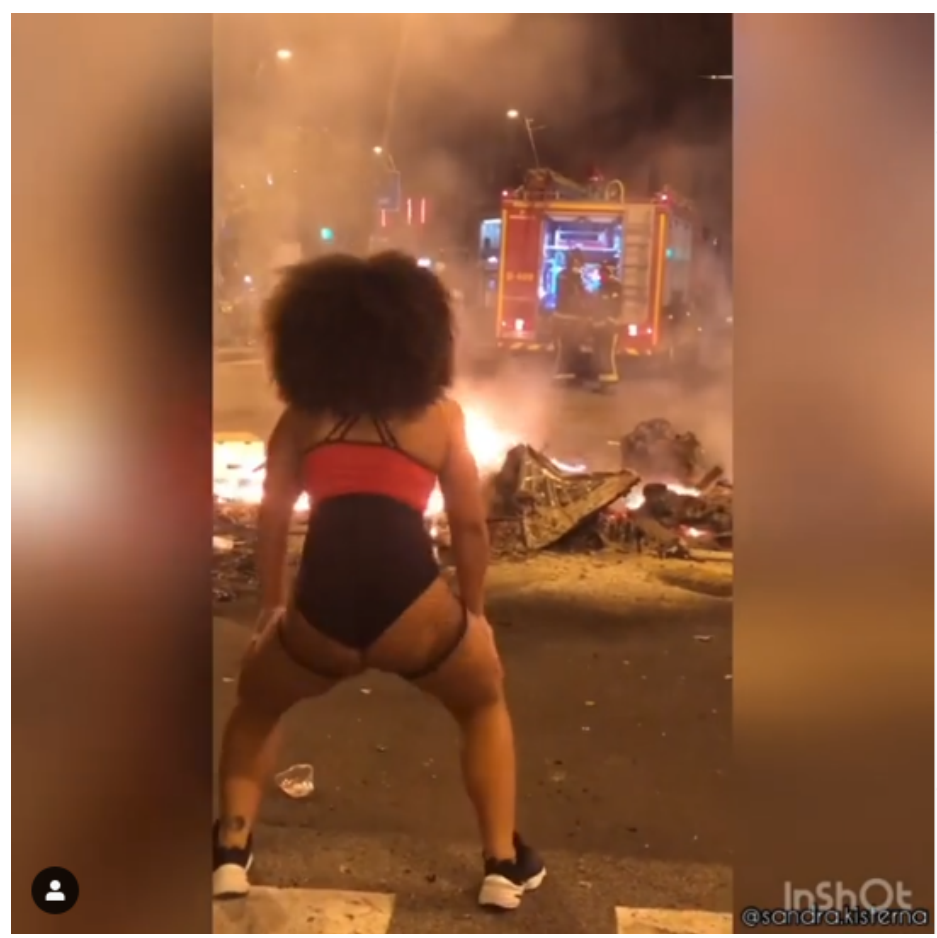

sandra.kisterna • Seguir

Barcelona, Spain

may gente que se manıтiesta sallenco a

la calle con violencia y yo no soy

partícipe de ello. Lo que vi ayer por la

noche en Barcelona era devastador, mi

querida ciudad arruinada, donde solo

reinaba el caos.

Y quiero decir también que habían

muchos niñ@s que no protestaban

por sus derechos, si no que les hacía

gracia ir corriendo por todas partes y

romper todo cuanto se encontraban a

sus pasos, y eso si que es triste de

verdad.

Aclarado todo esto, solo me queda

deciros que por favor sigamos

luchando pero sin tanta violencia

porque estamos destrozando

NUESTRA CIUDAD (2)

\#Barcelona \#LibertadDeExpresion

\#Baila

$12 \mathrm{sem}$

○

537,746 reproducciones

19 DE OCTUBRE DE 2019

Figura 14. Vídeo 2: Instagram de sandra.kisterna 


\section{DISERTACIONES}

\section{Clasificación de las imágenes}

Las ocho imágenes seleccionadas y los dos vídeos han generado distintas reacciones e interacciones, provienen de usuarios con perfiles distintos y un impacto en redes que oscila considerablemente en algunos casos. Para enmarcar el análisis formal de las imágenes, se procede a resumir las características básicas de documento audiovisual en una pequeña tabla. Se han clasificado las imágenes atendiendo a los siguientes criterios:

- Nombre de usuario: identificación del usuario en Instagram.

- Tipo de usuario: se distingue entre particulares que hacen uso personal de la cuenta, influencers/profesionales con gran impacto en redes con un número de seguidores superior a los 2.000 y profesionales del periodismo.

- Fecha: fecha de subida de la publicación, habiéndose realizado la consulta y elaboración de las tablas el día 12 de enero del 2020.

- Encuadre de la descripción: actitud de enmarcar las protestas. Se procedió a un sistema sencillo dividido en encuadre activo, mediante el cual el usuario se siente parte de la protesta y manifiesta una actitud de participación en la misma patente de la imagen o la descripción; pasiva, si el usuario se limita a reproducir un símbolo de la protesta y enmarcar su publicación durante las protestas sin participar en ellas; y neutro que no se asocia con objetivo, sino con la actitud de los tres fotoperiodistas reunidos en la muestra que manifiestan una actitud informativa en la descripción y etiquetado de la publicación, al margen de la actitud del sujeto representado.

- Interacciones: número de Me gusta o Reproducciones, con variabilidad en el impacto y número de impresiones en Instagram.

- Comentarios: tipos de comentarios patentes en las respuestas. Los comentarios de refuerzo apoyan la publicación de manera clara dando soporte en forma de palabras de ánimo, soflamas o emoticonos asociados con la protesta tales como llamas; los comentarios de contraprotesta son negativos y manifiestan una actitud contraria a la publicación señalando su carácter violento, agresivo o irrespetuoso; y los llamados comentarios escépticos que no se posicionan ni a favor ni en contra, sino que arrojan duda sobre el valor de las imágenes.

- Rasgos formales: se señalan una serie de rasgos formales comunes para poder entender las constantes estilísticas de la muestra seleccionada y extraer un determinado patrón visual que conforma la memoria colectiva del espacio digital de protesta. 


\section{DISERTACIONES}

ESTUDIOS

Grupos minoritarios y estigmatizados: diversidad funcional, religiosa, étnica, afectivo-sexual o de identidad de género en la comunicación

ISSN: $1856-9536$

Doi: https://doi.org/10.12804/revistas.urosario.edu.co/disertaciones/a.11077

Volumen 15, Número 1 / Enero-junio 2022

Versión PDF para imprimir desde

http://revistas.urosario.edu.co/index.php/disertaciones

Tabla 1. Plantilla de análisis descriptivo de la muestra

\begin{tabular}{|c|c|c|c|c|c|c|}
\hline Usuario & Tipo de usuario & Fecha & $\begin{array}{l}\text { Encuadre en } \\
\text { descripción }\end{array}$ & Interacciones & Comentarios & $\begin{array}{l}\text { Rasgos } \\
\text { formales }\end{array}$ \\
\hline $\begin{array}{l}\text { fitness_mama } \\
\text { (Imagen 1) }\end{array}$ & $\begin{array}{l}\text { Influencer: modelo } \\
\text { fitness }\end{array}$ & 16 de octubre & $\begin{array}{l}\text { Activo: actitud de } \\
\text { inmersión en la } \\
\text { protesta }\end{array}$ & 17.780 Me gusta & $\begin{array}{ll}\text { - } & \text { Refuerzo } \\
\text { - } & \text { Contraprotesta } \\
\text { - } & \text { Escépticos }\end{array}$ & $\begin{array}{l}\text { Figura humana en } \\
\text { primer plano, llamas } \\
\text { en el fondo, } \\
\text { angulación neutra }\end{array}$ \\
\hline $\begin{array}{l}\text { Tinyhandsbigheart } \\
\text { (Imagen 2) }\end{array}$ & $\begin{array}{l}\text { Particular: } \\
\text { ilustradora de } \\
\text { cómics }\end{array}$ & 26 de octubre & $\begin{array}{l}\text { Pasivo: asimila la } \\
\text { protesta como } \\
\text { objeto estético }\end{array}$ & 99 Me gusta & - Refuerzo & $\begin{array}{l}\text { Figura humana, } \\
\text { elemento simbólico } \\
\text { de protesta } \\
\text { (contenedor), } \\
\text { angulación neutra }\end{array}$ \\
\hline $\begin{array}{l}\text { Jordiborrasfoto } \\
\text { (Imagen 3) }\end{array}$ & $\begin{array}{l}\text { Profesional: } \\
\text { fotoperiodista }\end{array}$ & 24 de octubre & $\begin{array}{l}\text { Neutro: encuadra la } \\
\text { protesta } \\
\text { informativamente. }\end{array}$ & 8.742 Me gusta & $\begin{array}{ll}\text { - } & \text { Refuerzo } \\
\text { - } & \text { Contraprotesta }\end{array}$ & $\begin{array}{l}\text { Figura humana en } \\
\text { primer plano, llamas } \\
\text { en el fondo, } \\
\text { angulación neutra }\end{array}$ \\
\hline $\begin{array}{l}\text { Jordiborrasfoto } \\
\text { (Imagen 4) }\end{array}$ & $\begin{array}{l}\text { Profesional: } \\
\text { fotoperiodista }\end{array}$ & 16 de octubre & $\begin{array}{l}\text { Neutro: encuadra la } \\
\text { protesta } \\
\text { informativamente. }\end{array}$ & $20.5^{8} 4 \mathrm{Me}$ gusta & $\begin{array}{ll}\text { - } & \text { Refuerzo } \\
\text { - } & \text { Contraprotesta } \\
\text { - } & \text { Escépticos }\end{array}$ & $\begin{array}{l}\text { Figura humana en } \\
\text { primer plano, llamas } \\
\text { en el fondo, } \\
\text { angulación neutra }\end{array}$ \\
\hline $\begin{array}{l}\text { Official_yungsaber } \\
\text { (Imagen 5) }\end{array}$ & Influencer: músico & 17 de octubre & $\begin{array}{l}\text { Activo: actitud de } \\
\text { inmersión en la } \\
\text { protesta }\end{array}$ & 175 me gusta & $\begin{array}{ll}\text { - } & \text { Refuerzo } \\
\text { - } & \text { Contraprotesta } \\
\text { - } & \text { Escépticos }\end{array}$ & $\begin{array}{l}\text { Figura humana en } \\
\text { primer plano, llamas } \\
\text { en el fondo, } \\
\text { angulación neutra }\end{array}$ \\
\hline
\end{tabular}

\begin{tabular}{|c|c|c|c|c|c|c|}
\hline Usuario & Tipo de usuario & Fecha & $\begin{array}{l}\text { Encuadre en } \\
\text { descripción }\end{array}$ & $\begin{array}{l}\text { Interaccio } \\
\text { nes }\end{array}$ & Comentarios & Rasgos formales \\
\hline $\begin{array}{l}\text { Xaviherrero3 } \\
\text { (Imagen 6) }\end{array}$ & $\begin{array}{l}\text { Profesional: } \\
\text { fotoperiodista }\end{array}$ & $\begin{array}{l}27 \text { de octubre } \\
\text { de } 2019\end{array}$ & $\begin{array}{l}\text { Neutro: encuadra la } \\
\text { protesta } \\
\text { informativamente. }\end{array}$ & 205 Me gusta & - Refuerzo & $\begin{array}{l}\text { Primerísimo primer plano } \\
\text { de un rostro embozado, } \\
\text { fondo difuminado y leve } \\
\text { contrapicado. }\end{array}$ \\
\hline $\begin{array}{l}\text { Xphasis } \\
\text { (Imagen 7) }\end{array}$ & Particular: fotógrafo & $\begin{array}{l}19 \text { de octubre } \\
\text { de } 2019\end{array}$ & $\begin{array}{l}\text { Neutro: encuadra la } \\
\text { protesta } \\
\text { informativamente. }\end{array}$ & 40 Me gusta & $\begin{array}{l}\text { - } \text { Refuerzo } \\
\text { - } \quad \text { Escéptico }\end{array}$ & $\begin{array}{l}\text { Figura humana en primer } \\
\text { plano, llamas en el fondo, } \\
\text { angulación neutra. }\end{array}$ \\
\hline $\begin{array}{l}\text { Victoria_Rovira } \\
\text { (Imagen 8) }\end{array}$ & $\begin{array}{l}\text { Profesional: } \\
\text { fotoperiodista }\end{array}$ & $\begin{array}{l}16 \text { de octubre } \\
\text { de } 2019\end{array}$ & $\begin{array}{l}\text { Neutro: encuadra la } \\
\text { protesta } \\
\text { informativamente. }\end{array}$ & 120 Me gusta & $\begin{array}{ll}\text { - } & \text { Refuerzo } \\
\text { - } & \text { Contraprotesta } \\
\text { - } & \text { Escépticos }\end{array}$ & $\begin{array}{l}\text { Figura humana en primer } \\
\text { plano, llamas en el fondo, } \\
\text { angulación neutra. }\end{array}$ \\
\hline $\begin{array}{l}\text { Gqmike } \\
\text { (Video 1) }\end{array}$ & Influencer: músico & $\begin{array}{l}22 \text { de octubre } \\
\text { de } 2019\end{array}$ & $\begin{array}{l}\text { Activo: actitud de } \\
\text { inmersión en la protesta }\end{array}$ & $\begin{array}{l}5.197 \\
\text { reproduccion } \\
\text { es }\end{array}$ & $\begin{array}{ll}\text { - } & \text { Refuerzo } \\
\text { - } & \text { Contraprotesta }\end{array}$ & $\begin{array}{l}\text { Figura humana en primer } \\
\text { plano, llamas en el fondo, } \\
\text { angulación neutra. } \\
\text { Travelling de retroceso en } \\
\text { slow motion con sonido } \\
\text { extradiegético. }\end{array}$ \\
\hline $\begin{array}{l}\text { Sandra.kisterna } \\
\text { (Vídeo 2) }\end{array}$ & Influencer: Bailarina & $\begin{array}{l}19 \text { de octubre } \\
\text { de } 2019\end{array}$ & $\begin{array}{l}\text { Activo: actitud de } \\
\text { inmersión en la protesta }\end{array}$ & $\begin{array}{l}537.811 \\
\text { reproduccion } \\
\text { es }\end{array}$ & $\begin{array}{ll}\text { - } & \text { Refuerzo } \\
\text { - } & \text { Contraprotesta } \\
\text { - Escépticos }\end{array}$ & $\begin{array}{l}\text { Figura humana en primer } \\
\text { plano, llamas en el fondo, } \\
\text { angulación neutra. } \\
\text { Panorámica horizontal, } \\
\text { zooms dramáticos y } \\
\text { sonido extradiegético. }\end{array}$ \\
\hline
\end{tabular}

Fuente: elaboración propia. 


\section{DISERTACIONES}

\section{Resultado del análisis descriptivo}

El análisis de las ocho imágenes seleccionadas y dos vídeos recogidos en Instagram a partir de los hashtags \#barcelonariots y \#sentenciaproces devela ciertos patrones visuales comunes y determinada actitud general de los usuarios que intercambian interacciones y comentarios para construir un espacio digital de protesta que crea su propia memoria del acontecimiento mediático. Siete de los diez ítems audiovisuales presentan a individuos interactuando frente a la cámara con las llamas de fondo. El motivo del fuego está muy presente en las instantáneas, incluso en las realizadas por fotoperiodistas como Victòria Rovira (figura 12), Jordi Borras (figura 7) o Xavi Herrero (figura 10). Los hashtags asociados con las publicaciones de fotoperiodistas se limitan a etiquetar de acuerdo con su calidad de fotoperiodistas y ahondan en la condición individual en lugar de recoger al colectivo de la protesta.

Esta característica muestra una diferencia relevante respecto a la línea mediática de grandes medios, cuyas coberturas asociaban la protesta con el colectivo independentista y cual material gráfico consistía en fotografías de gran formato que recogían a multitudes anónimas. En estas fotografías la figura humana ocupa el centro de la composición, en encuadres de angulación neutra y con la profundidad de campo difuminada y surcada por llamas en un afán por revestir al individuo de un carácter colectivo. El rostro del individuo aparece cubierto por una máscara, denotando la necesidad de asociar la protesta con lo colectivo a través de la figura anónima. Asimismo, estos fotoperiodistas cubren la perspectiva del manifestante, la cual no aparece reflejada en ninguna de las coberturas mediáticas, que optan por encuadres centrados en el colectivo o en los agentes de la ley. El resto de las imágenes captadas refuerzan el papel central de la figura en actitudes corporales dinámicas, con las llamas de fondo e incluso cuando el sujeto aparece en primer plano (figura 10) el rostro se encuentra cubierto. Si las descripciones de las imágenes de los dos fotoperiodistas citados eran asépticas y se limitaban a describir el contexto de la imagen, los usuarios particulares que aparecen en la muestra sí desvelan distintas actitudes insertas en el texto con el que deciden acompañar la instantánea. En el caso concreto de Sandra.kisterna, su vídeo realizando twerking le obligó a bloquear los comentarios.

Por lo tanto, se aprecia una actitud de protesta clara y explícita con un acto de danza frente a las llamas, a las etiquetas de los medios de comunicación y la actitud meramente descriptiva - en el mejor de los casos-de las noticias que recogieron su publicación. El otro vídeo seleccionado (figura 13) perteneciente a la cuenta de gqmike incide en una puesta en escena similar al resto de material analizado. La presencia de llamas, la importancia del individuo y su actitud gestual, la interiorización de la protesta como escenario estético y la angulación neutra para incidir en la profundidad de campo y el fondo difuminado. En este caso, su actitud es más cercana a la de fitness_mama al construir una narrativa personal y proponer un simulacro cercano al de un videoclip musical. Existe un intento de conciliar el acto de protesta simbólico con la apropiación de la protesta, dado que la publicación se emplea para promocionar el lanzamiento de un videoclip musical. No se vacía de significado el acto de protesta, sino que se reifica sin lograr una integración. Los comentarios oscilan entre la aprobación con emoticonos de llamas y la contraprotesta de usuarios.

Por otra parte, en la instantánea de Jordi Borras (figura 7), si bien la actitud del periodista es meramente informativa, más reivindicativa es la de los usuarios y sus comentarios: desde emojis con llamas, pasando por soflamas como "Fuck capitalism", menciones a la empresa Glovo, y usuarios contraprotestando y apuntando al carácter criminal de los manifestantes. Las publicaciones de influencers, en concreto el músico oficial_yungsabery 


\section{DISERTACIONES}

ESTUDIOS

Grupos minoritarios y estigmatizados: diversidad funcional, religiosa, étnica, afectivo-sexual o de identidad de

género en la comunicación

ISSN: $1856-9536$

Doi: https://doi.org/10.12804/revistas.urosario.edu.co/disertaciones/a.11077

Volumen 15, Número 1 / Enero-junio 2022

Versión PDF para imprimir desde

http://revistas.urosario.edu.co/index.php/disertaciones

la modelo fitness fitness_mama -únicos usuarios que exponen su rostro- muestran una actitud que oscila entre el exhibicionismo, la marca personal y la reivindicación: el primero empleando el hashtag \#barcelonariots seguido de un emoji que realiza el gesto del dub; la segunda acompañando la frase "Barcelona is on fire!" con varios emoticonos de llamas y una descripción en ruso. Las interacciones, entonces, oscilan entre la aceptación con el emoticono de las llamas destacando sobre otros, el rechazo como acto de contraprotesta y el escepticismo que cuestiona la estilización de la protesta.

\section{Resultados del análisis de encuadre}

De Doerr y Teune (2008) se adquieren los encuadres necesarios para reflexionar sobre cómo los usuarios de las ocho imágenes seleccionadas reencuadran la protesta y construyen por medio de la interfaz el espacio digital de protesta. Los procesos de transmisión y relación entre imágenes son directos, mediante un hashtag que conecta y agrupa las imágenes a partir de tags que derivan de la protesta - para esta selección se han empleado los hashtags \#barcelonariots y \#sentenciaproces, ya que eran los que proporcionaban un mayor número de resultados-, y también indirectos a través de un proceso de mediación (Doerr \& Teune, 2008, p. 162) que descubre la capacidad de las imágenes para generar valores icónicos comunes, estimular interacciones y construir una memoria visual de motivos estilizados que conforman el imaginario común y el espacio digital.

Doerr y Teune (2008) proponen cuatro tipos de reacciones a estos encuadres, las cuales pueden readaptarse y considerarse encuadres en sí mismos: el de rechazo, porque atenta contra un sistema de valores hegemónico; el de contención, que asigna cierta legitimidad factual al encuadre con base en iconos en forma de símbolos de la protesta, pero sin erigirse en un ejemplo de imagen que concentra todo el valor simbólico del espacio digital; el de apropiación, que vacía de significado político un icono y lo erige en una imagen que estiliza la protesta; y el de integración, que aúna el sistema de valores hegemónico mediante un icono en forma de símbolo que pasa a ser representativo de todo el espacio digital de protesta. Los diez recursos audiovisuales - ocho imágenes y dos vídeos- serán clasificados atendiendo a estas cuatro reacciones originarias que, para fines de este análisis, se convertirán en tipos de encuadre con entidad y significación propios. Posteriormente, partiendo del trabajo de Zappavigna (2016) se analizará la conexión interpersonal entre las imágenes, atendiendo a la idea de negociación intersubjetiva y al análisis de las imágenes para esbozar una propuesta de significado interpersonal que desvele las conexiones que se producen por medio de la interfaz y operan en el espacio digital de protesta. Este imaginario común se articula a partir de la negociación interpersonal entre el usuario, el receptor y la imagen que, para Zappavigna (2016, p. 276), se organiza en un sistema que involucra la posición del individuo, la actitud y el contacto. En esta negociación existen dos mecanismos (Zappavigna, 2016, p. 276): la focalización, que conecta lo representado con el receptor, y la subjetivización que conecta al usuario que postea la imagen y el receptor. Para explicar lo primero se recurre a un análisis visual de la imagen, y para ahondar en lo segundo se recurre a ideas como la performatividad y la estetización.

Partiendo de los encuadres elucidados y descritos, se ha definido la siguiente clasificación de imágenes. En esa línea, se ha realizado una adaptación de los encuadres propuestos por Doerr y Teune (2008) transformando lo que ambos autores consideran reacciones ante las imágenes de protesta en encuadres adoptados por los usuarios. Mientras que Doerr y Teune proponen marcos como respuesta a la representación del activismo, los encuadres 
de esta investigación pretenden mostrar el de estas minorías a través de su propia producción de imágenes en Instagram. Doerr y Teune (2008, p. 6) distinguían un encuadre de rechazo -incompatibles con un sistema de valores hegemónico-, uno de contención -el encuadre es legitimado en parte, pero rechazado dado que no alberga valores más universales dentro de una protesta-, uno de apropiación -el encuadre es vaciado de capacidad subversiva y se cosifica para obtener un valor mercantil-, y uno de integración -existe una sincronía entre un sistema hegemónico de valores como podría ser el respeto a la democracia y un elemento simbólico de la protesta como una pancarta a favor de ese valor universal-.

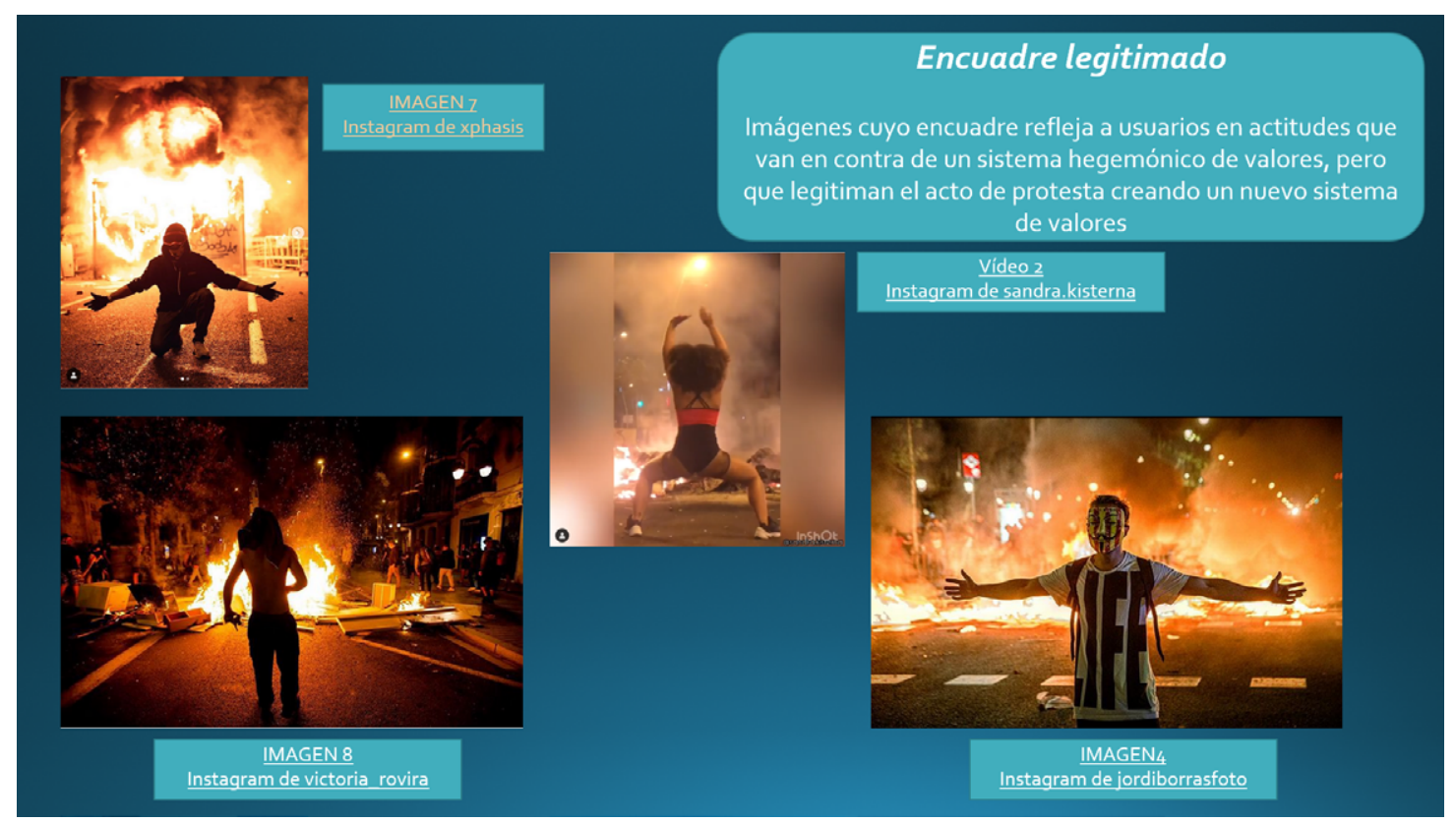

Figura 15. Encuadre legitimado: la legitimación del acto de protesta

Son imágenes que reflejan a individuos en actitudes que atentan contra un sistema hegemónico de valores definido en criterios como la legalidad jurídica y la subversión del orden público habitual, sin entrar en juicios valorativos y legales. Pese a ir en contra de un sistema de valores institucionalizado, las imágenes y actitudes de protesta muestran cierto orgullo, o como mínimo, aceptación de los fuegos como instrumento de protesta. Así bien, se podría afirmar que conforman un sistema de valores nativo del espacio digital de protesta. Las imágenes de Instagram muestran una atracción hacia ese gran elemento simbólico y concreto que es el fuego, hacia el objeto de la propuesta: el lenguaje corporal es expansivo -brazos abiertos, piernas abiertas, corriendo hacia el fuego-, pretenden abrazar el fuego, apropiarse de él, y consecuentemente, de la protesta.

Así mismo, está clasificación permite vislumbrar la importancia del individuo en la composición, facilitando una concepción del espacio digital de protesta como una forma de activismo que desplaza la preponderancia del colectivo de la protesta al individuo. De igual manera, se concluye que el objeto de la protesta -mostrar el descontento con la sentencia - se diluye en la escenografía de ese objeto de protesta: llamas, máscaras, rostros tapados 


\section{DISERTACIONES}

ESTUDIOS

Grupos minoritarios y estigmatizados: diversidad funcional, religiosa, étnica, afectivo-sexual o de identidad de género en la comunicación

y una puesta en escena al servicio de la estetización. Lo mismo sucede con el vídeo de la usuaria Sandra.kisterna, realizando twerking alrededor de las llamas introduciendo un sonido extradiegético en forma de la canción "La calle bota fuego", de Bad Bunny y El Alfa.

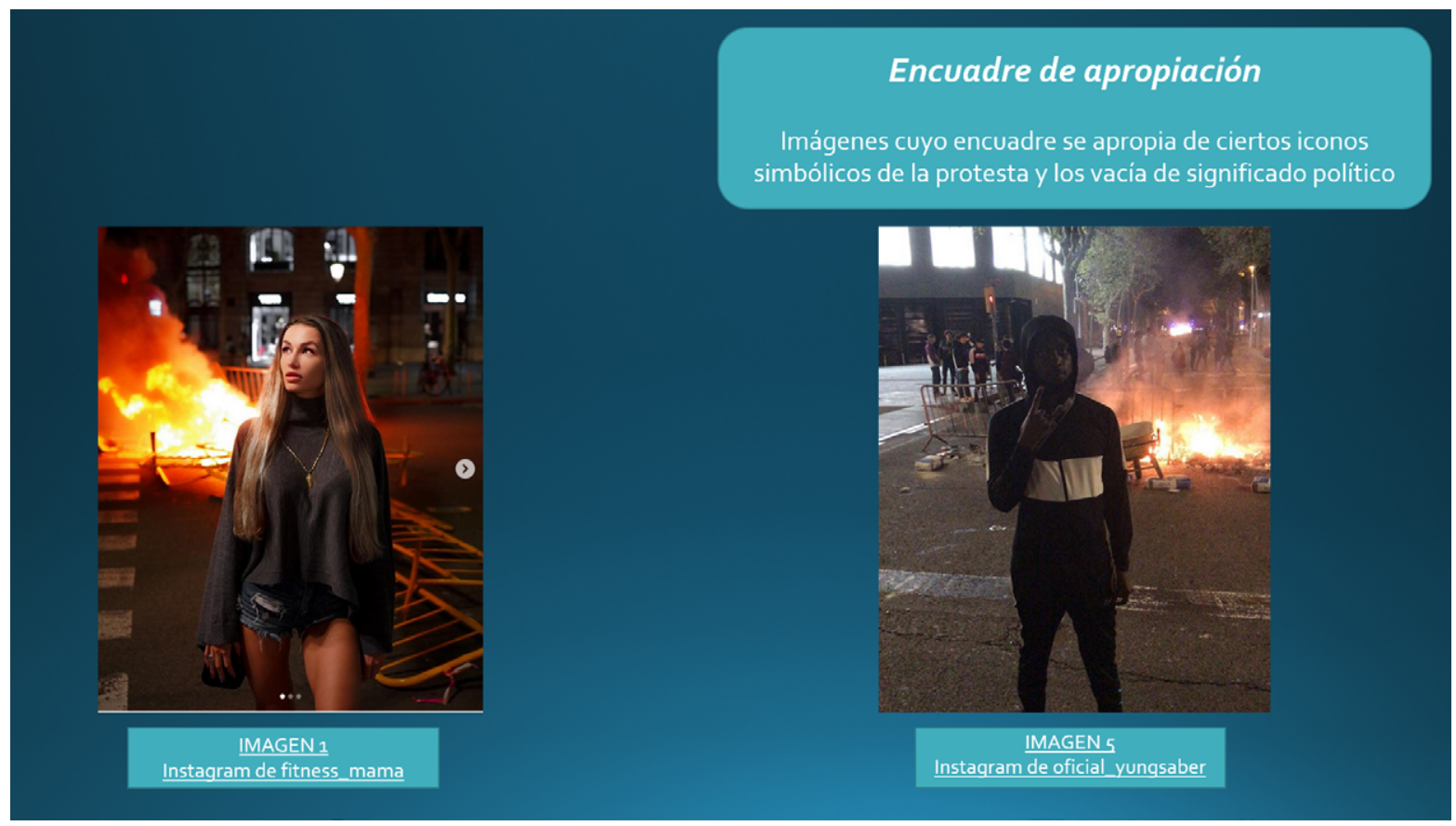

Figura 16. Encuadre de apropiación: la cuestión del vaciamiento de la carga política

El segundo par de imágenes se engloba bajo un encuadre de apropiación, en el que los individuos o usuarios se apropian de ciertos iconos simbólicos de la protesta, los vacía de significado y se sitúan en el centro de la imagen en un proceso de negociación intersubjetiva que solo busca la interacción y la ganancia de valor simbólico en relación a criterios como la propia imagen. El selfie, el uso de FaceApp o los presagios de las composiciones con DeepFake remiten a un uso del rostro como punto de contacto entre la interfaz y el individuo (Munster, 2006), un espacio cognitivo en el que los nuevos medios y los creadores proponen puntos de encuentro. A través del individuo se construyen universos audiovisuales que desdoblan el flujo mediático en mundos hipotéticos cuya temporalidad y espacialidad se compactan en una subjetividad concreta: el rediseño de interfaces que sean capaces de contener una imagen determinada de un presente tan lánguido como absorto en su propio reflejo. El signo de una imagen en redes sociales también es icónico, siguiendo la clasificación de Pierce, dado que posee parte de las propiedades de la cosa que representa. Esa imagen, aislada de la interfaz y el entorno de interacción, perdería gran parte de su carácter de signo. Son imágenes cuyo significado es negociado, sin que existan hegemonías dominantes o posiciones de poder. Como apunta Martín Prada (2018, p. 33), las relaciones en las redes sociales se articulan en flujos afectivos basados en impulsos momentáneos, interacciones a corto plazo que buscan la gratificación instantánea y generan imágenes difusas y carentes de sentido. El propio Martín Prada (2018), al elucidar esta lógica de la instantaneidad 


\section{DISERTACIONES}

ESTUDIOS

Grupos minoritarios y estigmatizados: diversidad funcional, religiosa, étnica, afectivo-sexual o de identidad de género en la comunicación

señala la distancia de esta clase de relaciones e imágenes de lo efímero como melancólico y propone un carácter efímero e hipnótico: este encuadre muestra a individuos en imágenes que más que mirar al mundo, ven a la imagen que crean del mundo a través de su publicación, suscitando una emoción que genere interacciones en forma de likes.

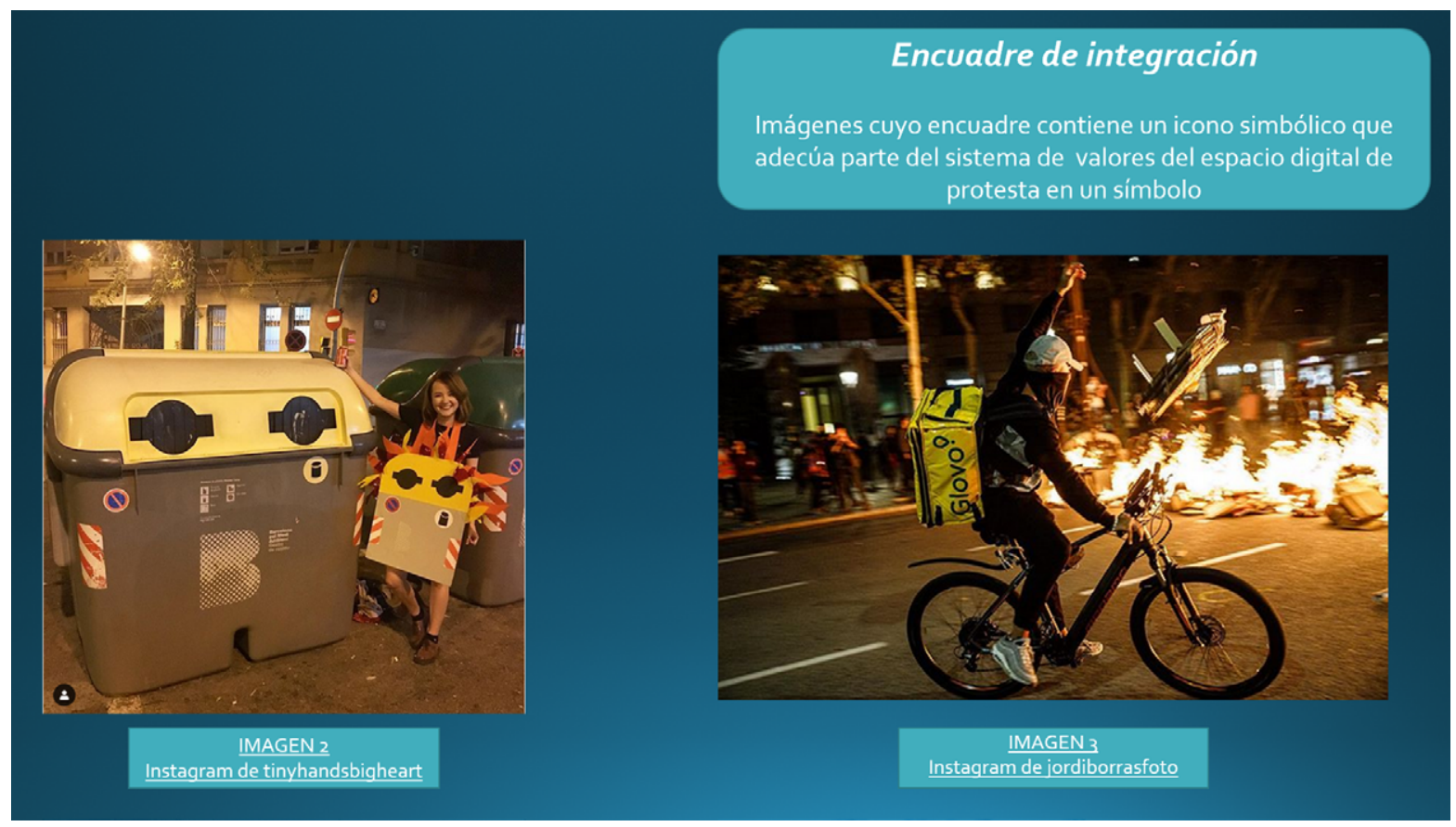

Figura 17. Encuadre de integración: la adecuación de icono simbólico y sistema de valores

El tercer par de imágenes analizadas (figura 6 y 7 ) se relacionan con un encuadre de integración en el que las imágenes presentan un determinado carácter simbólico que refleja el sistema de valores del espacio digital de protesta. En la imagen 2, el disfraz de un contenedor ardiendo y la fotografía de la usuaria posando al lado de un contenedor real, aúna uno de los iconos reales de la protesta con uno recurrente en el espacio digital mediante el cual se ironiza. En la imagen 3 se presenta un caso de imagen viralizada en redes a partir de la instantánea captada y subida a la cuenta de un fotógrafo profesional. El icono del trabajador de una empresa de reparto a domicilio, con el significado asociado a esa empresa por el imaginario colectivo - precariedad laboral y condiciones de trabajo poco adecuadas-, rápidamente se viralizó como un icono inherente al espacio digital de protesta y parte de una nueva memoria e imaginario colectivo; una imagen en forma de prótesis visual que condiciona la manera de relacionarse con la protesta mediante un proceso de estetización. La ironía es una de las relaciones principales que se establece a partir de la interacción por medio de la interfaz. Dicha ironía se basa en una apropiación de iconos habitualmente imbuidos de una carga simbólica negativa -los repartidores, los contenedores ardiendo, entre otros- y revierte la valencia de este símbolo otorgándole una carga reivindicativa y metareflexiva: el icono pasa a ser observado desde fuera como objeto de reflexión, estimulando la autoconsciencia de los receptores. Zafra (2010) considera que la ironía es el único mecanismo relacional capaz de reapropiarse de la barbarie en forma de 


\section{DISERTACIONES}

ESTUDIOS

Grupos minoritarios y estigmatizados: diversidad funcional, religiosa, étnica, afectivo-sexual o de identidad de género en la comunicación

ISSN: $1856-9536$

Doi: https://doi.org/10.12804/revistas.urosario.edu.co/disertaciones/a.11077

Volumen 15, Número 1 / Enero-junio 2022

Versión PDF para imprimir desde

http://revistas.urosario.edu.co/index.php/disertaciones

caos de imágenes y esquemas de pensamiento insertos en Internet y en las redes sociales, considerándola junto a la parodia como instrumentos de creación de minorías digitales alrededor de esquemas de pensamiento críticos.

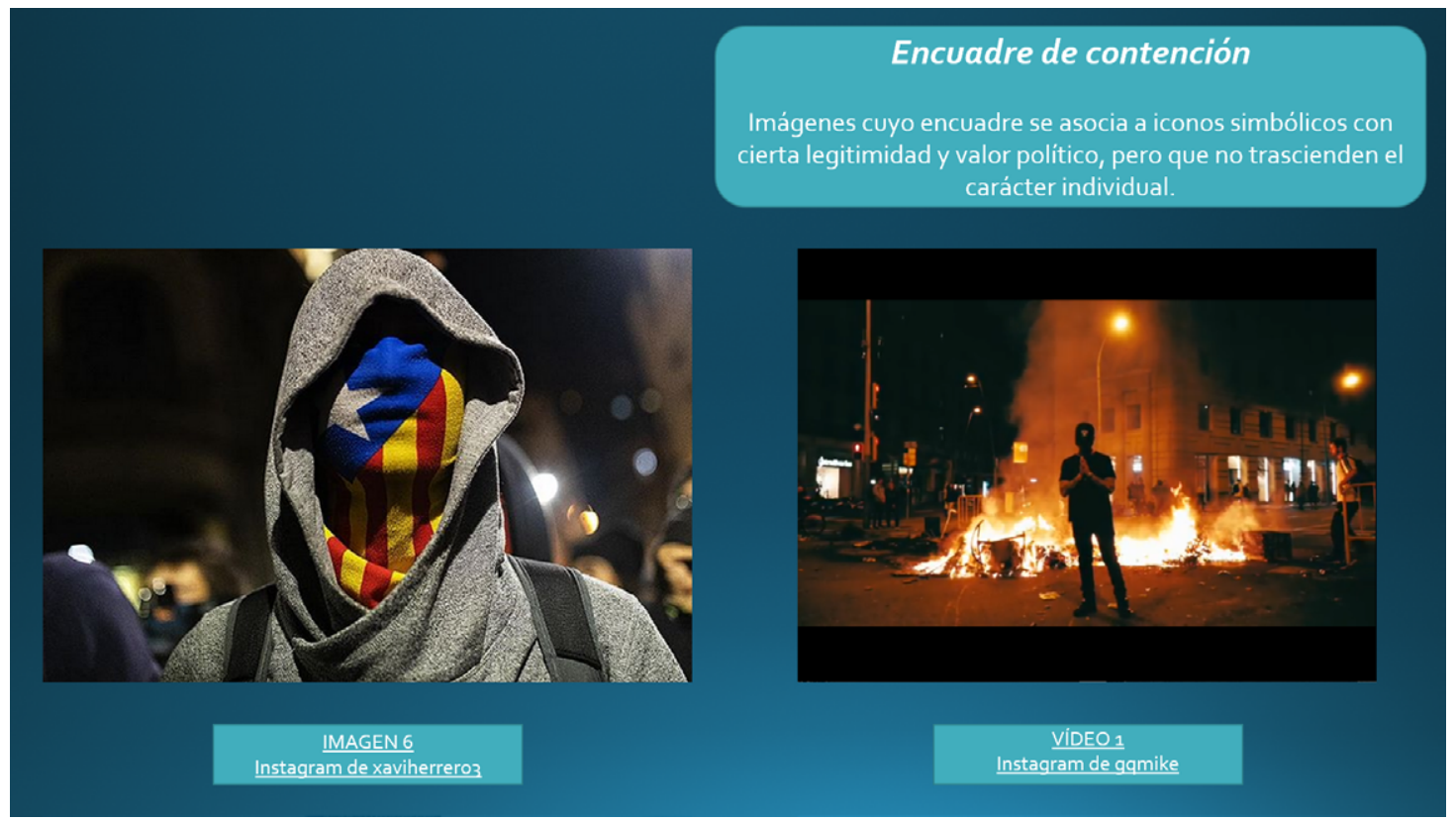

Figura 18. Encuadre de contención: el vídeo de gqmike y la cuestión del símbolo individualizado

El último par de imágenes se articulan en un encuadre de contención según el cual los usuarios recurren a ciertos iconos simbólicos dotados de cierta legitimidad -la estelada como icono político y el gesto del penitente completamente desposeído de valor religioso-, pero que no trascienden el carácter individual debido a factores como la falta de impacto e interacciones o el carácter meramente estético de las instantáneas. Nuevamente son imágenes en las que el individuo ocupa el centro de la composición, con iconos presentes en la máscara con los colores de la estelada o en el vídeo de un músico que adopta una pose penitente con un sonido extradiegético que intercala tonos de sirenas y campanas, sin que ese simbolismo más o menos elaborado, se viralice y extienda a otros registros audiovisuales de la misma protesta.

\section{Conclusiones}

El objetivo principal de este estudio era desvelar algunos de los mecanismos que han contribuido a conformar lo que se ha denominado el espacio digital de protesta surgido de las manifestaciones tras la sentencia del juicio sobre el Procés. El análisis de imágenes reveló los encuadres adoptados por los usuarios de minorías que acudieron a las protestas: desde aquellos que la emplean como un recurso para proponer una estilización que se apropia de ciertos iconos simbólicos para extraer una ganancia en valor simbólico y afectivo, hasta aquellas imágenes que, partiendo del individuo, se erigen a través de la viralización en iconos simbólicos nativos del espacio digital de 


\section{DISERTACIONES}

ESTUDIOS

protesta. Aunque este estudio no pretenda ser representativo, estos encuadres revelan que las relaciones basadas en la intersubjetividad emanan necesariamente de procesos como la interacción, la viralización y la subjetivización. En concreto, esta última permite entender un proceso clave en las nuevas formas de activismo audiovisual surgidas en el seno del espacio digital de protesta. Este proceso es la asimilación de lo colectivo en lo individual mediante una transferencia que individualiza al colectivo en imágenes cuyas composiciones privilegian el antropocentrismo. El periodista que bucee por los hashtags, las tendencias y las interacciones en Instagram se topará con que el objeto de protesta ha sido sustituido por la importancia de la relación del individuo con el espacio real de protesta. El acto político, la reivindicación o el fenómeno contra el que se protesta ya no centra el relato inserto en la imagen, sino que su performatividad - su capacidad para generar significado por sí sola - se articula en la micronarración del usuario que propone su acto de visión sobre la protesta. El análisis de la estetización motiva comprender la intersubjetividad como detonante de un régimen escópico, de un sistema de mirar y relacionarse con otros a través de la imagen, en el que la imagen del individuo ya no intenta ser una ventana abierta al mundo -en este caso, una protesta política - sino una puerta a un cuarto digital propio conectado con otros. El espacio digital de protesta -en esta ocasión concreta tiene unas circunstancias especiales a través de la cristalización de una rabia y emociones en elementos de organización con las propias redes-emana de este imaginario colectivo compuesto de micronarraciones individuales. La forma de acceder a él es por medio de una memoria prostética -integrada por iconos simbólicos como las llamas, las máscaras o una empresa de reparto- construida en relaciones intersubjetivas basadas en el intercambio de dones - likes, interacciones y vistas- que generan expectativas y compromisos. El valor de intercambio inserto en las relaciones en este espacio digital de protesta, se genera a partir de códigos incorporados en la imagen y analizados por su composición: la posición del individuo, la actitud y el contacto. Estos códigos conforman un lenguaje común que, interpretado debidamente, permite comprender el marco de relaciones intersubjetivas como un sistema que en el caso de las protestas del Procés genera un escenario digital de protesta basado en la apropiación, la ironía y la estetización.

El carácter político se desplaza y queda el carácter social e iconográfico. La protesta colectiva se convierte en un acto de visión individual y el descontento de los manifestantes se traduce en un régimen de creencia (Brea, 2007, p. 152), un sistema que desvela cómo se cree en la protesta más que proponer una participación activa en la misma. Instagram se ha erigido en una institución social que genera, con su timeline de imágenes, un inconsciente óptico entendido como el acto de mirar y desplazar imágenes sin reflexión. El espacio digital de protesta del Procés es una concreción de esa institución social: imágenes conectadas por iconos, por encuadres y por mecanismos de composición de imagen e interacción. El inconsciente óptico diluye la reivindicación e impone un acto de recepción acrítico y estetizado, pero al mismo tiempo, repleto de potencialidad: el usuario quiere participar en la protesta real y las imágenes se mueven en el terreno del activismo deseado y no de la implicación política práctica. 


\section{DISERTACIONES}

ESTUDIOS

\section{Referencias}

1. Arrechedera, L.P., \& Villanueva, N. (2019, 17 de octubre). Todas las claves de la sentencia del juicio del «procés». ABc. https://www.abc.es/espana/abci-todas-claves-sentencia-juicio-proces-201910141105_noticia.html

2. Agencia EFE. (2019, 16 de octubre). Las protestas independentistas provocan este martes 74 heridos en Cataluña. EFE. https://www.efe.com/efe/espana/politica/las-protestas-independentistas-provocan-este-martes-74-heridos-en-cataluna/10002-4087768

3. Anderson, P. (2019). Independence 2.0: Digital activism, social media and the Catalan indepence movement. Catalan Journal of Communication \& Cultural Studies, 11(2), 191-207. https://doi.org/10.1386/cjcs_00003_1

4. Blas, Z. (2013). Escaping the face: Biometric facial recognition and the facial weaponization suite. Media-N, Journal of the New Media Caucus. http://median.newmediacaucus.org/caa-conference-edition-2013/ escaping-the-face-biometric-facial-recognition-and-the-facial-weaponizationsuite/.

5. Brea, J. L. (2007). Cambio de régimen escópico: del inconsciente óptico a la e-image. Estudios Visuales: ensayo, teoría y crítica de la cultura visual y el arte contemporáneo, (4), 145-160.

6. Catalá Domènech, J. M. (2010). La imagen interfaz: representación audiovisual y conocimiento en la era de la complejidad. Universidad del País Vasco.

7. Doerr, N., \& Teune, S. (2008). Visual codes in movement. When the protest imagery hits the establishment. European Protest Movements, 157-170. https://protestkuriosa.files.wordpress.com/2008/05/doerr-teune.pdf

8. Dubois, P., \& Villeneuve-Siconnelly, K. (2019). Framing Catalonia: Evidence from Québec media. Catalan Journal of Communication \& Cultural Studies, 11(2), 227-247. https://doi.org/10.1386/cjcs_00005_1

9. Escolar, I. (2019, 14 de octubre). Ni golpe de Estado ni secesión ni violencia organizada ni rebelión. ElDiario. https://www.eldiario.es/escolar/golpe-secesion-violencia-organizada-rebelion_132_1163431.html

10. Ferreira Martín, A. (2020). Tecnopatías post-alfabéticas: lectoescritura performativa y somatización de Internet [Tesis de doctorado, Universidad Complutense de Madrid]. Repositorio Institucional de la ucm. https:// eprints.ucm.es/id/eprint/64934/

11. Fisher, M. (2017). Una revolución social y psíquica de magnitudes casi inconcedibles: los interrumpidos sueños aceleracionistas de la cultura popular. En A. Avanessian \& M. Reis (Eds.), Aceleracionismo: estrategias para una transición hacia el postcapitalismo (pp. 153-167). Caja Negra.

12. Floridi, L. (Ed.). (2016). The Onlife Manifesto. Being Human in a Hyperconnected Era. Springer.

13. Gómez Cruz, E., \& San Cornelio, G. (2018). Imagening discontent: Political images and civic protest. En M. Rohr \& B. Sliwinska (Eds.), The Evolution of the Image: Political Action and the Digital Self (pp. 44-66). Routledge.

14. Groys, B. (2016). Arte en flujo. Caja Negra.

15. Hui, Y. (2019). The question concerning technology in China: An essay in Cosmotechnics. Miт Press.

16. Igartua, J.J., \& Humanes, M.L. (2004). Teoría e Investigación en Comunicación Social. Editorial Síntesis.

17. Illouz, E. (2007). Cold intimacies: The making of emotional capitalism. Polity Press. 


\section{DISERTACIONES}

ESTUDIOS

Grupos minoritarios y estigmatizados: diversidad funcional, religiosa, étnica, afectivo-sexual o de identidad de

18. Izquierdo Magaldi, B., Renés Arellano, P., \& Gómez Cash, O. (2013). La alfabetización mediática en la universidad a través de talleres multimodales de lectura y escritura académicas. Edmetic: Revista de Educación Mediática y тIC, 2(2), 76-94. https://doi.org/10.21071/edmetic.v2i2.2871

19. Kim, S. H., Scheufele, D. A., \& Shanahan, J. (2002). Think about it this way: Attribute Agenda-Setting function of the press and the public's evaluation of a local issue. Journalism and Mass Communication Quarterly, 79(1), 7-25. https://doi.org/10.1177/107769900207900102

20. Koliska, M., \& Roberts, J. (2015). Selfies: Witnessing and Participatory Journalism with a Point of View. International Journal of Communication, 9, 1672-1685. https://ijoc.org/index.php/ijoc/article/viewFile/3149/1392

21. Kuntsman, A. (2017). Introduction: Whose Selfie Citizenship?. En A. Kuntsman (Ed.), Selfie Citizenship (pp. 13-18). Palgrave Macmillan.

22. López-Cleries, G. (2020). Give Me More Triggers: el giro terapéutico en la industria cultural. Exit-Express.

23. Marcos, N. (2019, 15 de octubre). Iglesias, sobre el 'procés': "La sentencia es la excusa perfecta para el psoE para gobernar con el PP”. El País. https://elpais.com/politica/2019/10/15/actualidad/1571138606_957397.html

24. Martialay, Á., \& Marraco, M. (2019, 14 de octubre). El Supremo sentencia a Junqueras a 13 años por sedición con malversación y a entre nueve y 12 al resto de encarcelados por el 'procés'. El Mundo. https://www.elmundo.es/ espana/2019/10/14/5da4104f21efa0200a8b461c.html

25. Martín Prada, J. (2018). El ver y las imágenes en el tiempo de Internet. Akal.

26. Munster, A. (2006). Materializing New Media - Embodiment in Information Aesthetics. Darthmouth College Press.

27. Noguer, M., \& Baquero, C.S. (2019, 16 de octubre). Las protestas se radicalizan en Cataluña con el apoyo de Torra. El País. https://elpais.com/politica/2019/10/16/actualidad/1571184489_399283.html

28. San Cornelio, G., \& Gómez Cruz, E. (2019). Image-sharing and iconicity on social media during the Catalan conflict (2017). Catalan Journal of Communication \& Cultural Studies, 11(2), 289-301. https://doi.org/10.1386/ cjcs_00008_1

29. Semetko, H. A., \& Valkenburg, P. M. (2000). Framing European Politics: A content analysis of press and television news. Journal of Communication, 50(2), 93-109. https://doi.org/10.1111/j.1460-2466.2000.tb02843.x

30. Tankard, J. W. (2001). The empirical approach to the study of media framing. En S.D. Reese, O.H. Gandy \& A.E Grant (Eds.), Framing public life. Perspectives on media and our understanding of the social world (pp. 95-106). Lawrence Erlbaum Associates.

31. Tort, Á. (2019, 16 de octubre). Las protestas derivan en una oleada de violencia en Catalunya. La Vanguardia. https://www.lavanguardia.com/politica/20191016/471019551059/protestas-sentencia-proces-cataluna-disturbios-violencia-mossos.html

32. Treré, E., \& Barassi, V. (2015). Net-authoritarianism? How web ideologies reinforce political hierarchies in the Italian 5 Star Movement. Journal of Italian Cinema \& Media Studies, 3(3), 287-304. https://doi. org/10.1386/jicms.3.3.287_1

33. Treré, E., Jeppesen, S., \& Mattoni, A. (2017). Comparing Digital Protest Media Imaginaries: Anti-austerity Movements in Spain, Italy \& Greece. TripleC: Communication, Capitalism \& Critique. Open Access Journal for a Global Sustainable Information Society, 15(2), 404-422. https://doi.org/10.31269/triplec.v15i2.772

34. Van Dijck, J. (2008). Digital photography: Communication, identity, memory. Visual Communication, 7(1), 57-76. https://doi.org/10.1177/1470357207084865 


\section{DISERTACIONES}

\section{ESTUDIOS}

35. Watkins, E. A. (2014). Towards a Theory of Hiperstory: From the here and now to the everywhere and Forever. The Enemy.

36. Zafra, R. (2010). Un cuarto propio conectado: (Ciber)espacio y (auto)gestión del yo. Fórcola Ediciones.

37. Zappavigna, M. (2016). Social media photography: Construing subjectivity in Instagram images. Visual Communication, 15(3), 271-292. https://doi.org/10.1177/1470357216643220 